\title{
MODEL PENINGKATAN KINERJA SISTEM LOGISTIK YANG EFEKTIF DAN EFISIEN
}

\author{
Cundo Harimurti \\ Program Studi Manajemen Logistik \\ Institut Ilmu Sosial dan Manajemen STIAMI \\ Email: cundoharimurti@gmail.com
}

\begin{abstract}
Abstrak. Salah satu dampak globalisasi yang kemudian diikuti dengan berbagai perjanjian perdagangan bebas yang diterapkan di suatu kawasan mendorong persaingan dalam berbagai industri menjadi semakin ketat. Di kawasan ASEAN, implementasi Masyarakat Ekonomi ASEAN (MEA) memicu perlunya peningkatan kemampuan daya saing industri dalam negeri melalui peningkatan kinerja sistem logistiknya. Suatu model pengukuran peningkatan kinerja sistem logistik dirancang sebagai alat evaluasi bagi perusahaan komponen otomotif di Indonesia, untuk meningkatkan kinerja logistiknya sehingga mampu bersaing dalam konteks pasar bebas. Perancangan model pengukuran peningkatan kinerja sistem logistik ini berbasis pada perspektif Logistics Scorecard, dan terbagi dalam dua tahap: mengidentifikasi strategi bisnis rantai pasoklogistik untuk mendapatkan KPI, dan menyusun model pengukuran peningkatan kinerja sistem logistik. Terdapat 23 KPI menurut lima perspektif Logistics Scorecard. Penerapan model menghasilkan skor rata-rata kinerja logistik yang tergolong cukup baik dengan beberapa indikator yang perlu ditingkatkan. Hal ini dapat dijadikan pertimbangan dalam penentuan kebijakan dalam rangka meningkatkan kinerja sistem logistik yang efektif dan efisien yang berdaya saing tinggi.
\end{abstract}

Kata Kunci: Pengukuran Peningkatan Kinerja Sistem Logistik, Logistics Scorecard, Industri Komponen Otomotif, Daya Saing.

\section{Abstract.}

\section{A. PENDAhuluan}

Sistem logistik merupakan bagian integral dalam suatu aktivitas keseharian suatu organisasi yang kompleks sehingga memerlukan penanganan secara serius agar tercapai tingkat efektivitas dan efisiensi yang diharapkan. Dalam skala kecil, - seperti perusahaan -, kompleksitas sistem logistik masih terbatas pada bagaimana menciptakan keseimbangan antara supply barang dengan demand konsumen pengguna produk. Sedangkan pada skala yang lebih besar, tingkat wilayah atau nasional, kompleksitas sistem menjadi jauh lebih rumit mengingat banyaknya faktor sebab dan dampak yang dapat menjadi efek lanjutan dari sistem logistik nasional yang tidak efektif. Sistem logistik nasional tidak semata-mata hanya menyampaikan suatu barang (jadi) atau bermacam-macam material dalam jumlah yang tepat pada waktu yang dibutuhkan, efektif -, dan dengan total biaya yang minimal, - efisien -, tetapi bagaimana sistem logistik nasional mampu menjadi faktor leverage perekonomian daerah maupun nasional.

Ketidakseimbangan yang menjadi salah satu permasalahan sistem logistik nasional antara lain memang terletak pada ketidakseimbangan dalam artian jumlah dan jarak-sebaran antara sentra-sentra produksi dengan sentra-sentra konsumsi. Namun begitu, strategi meningkatkan, memindahkan atau mendekatkan sentra-sentra produksi ke daerah sentra konsumsi pun bukanlah merupakan penawaran solusi tepat, mengingat strategi tersebut cenderung mengabaikan faktor-faktor lain terkait, terutama faktor sosial dan budaya. 


\section{JURNAL LOGISTIK INDONESIA}

Majalah Ilmiah Institut STIAMI

ISSN 2579-8952

Untuk itu, perlu ditempuh strategi lain yang lebih menitikberatkan pada bagaimana suatu sistem logistik nasional dikelola dalam suatu management sistem logistik yang efektif dan efisien.

Pemerintah memiliki perhatian besar terhadap sistem logistik, sehingga perlu mengaturnya pada dalam suatu kebijakan nasional setingkat Peraturan Presiden atau Peraturan Pemerintah dengan melibatkan multi-sektor. Pada masa Pemerintahan Presiden Susilo Bambang Yudhoyono, Pemerintah menerbitkan Peraturan Presiden Tentang Sistem Logistik Nasional. Sedangkan kebijakan terbaru dalam konteks sistem logistik nasional pada saat ini antara lain adalah konsep Tol Laut yang digagas, diimplementasikan, serta diawasi secara serius oleh Presiden Joko Widodo. Harapannya, melalui Konsep Tol Laut ini sistem logistik nasional dapat terselenggara secara lebih terpadu sehingga tercipta kinerja sistem logistik nasional yang efektif dan efisien serta mampu mendongkrak tingkat daya saing nasional.

Sistem logistik nasional yang efektif dan efisien diperlukan karena dalam persaingan internasional dewasa ini, persaingan tidak hanya hanya antar produk dan antar perusahaan, namun antar rantai pasok dan bahkan antar negara (Heizer dan Render, 2011). Strategi penguatan sistem logistik nasional diperlukan untuk dapat meningkatkan kinerja logistiknya. Untuk itu perlu dilakukan pengukuran untuk mengetahui kinerja sistem logistik nasional. Artikel ini mengetengahkan hasil penelitian tentang bagaimana mengembangkan model pengukuran peningkatan kinerja sistem logistik yang efektif dan efisien dengan menggunakan permodelan pada industri otomatif.

\section{B. Tinjauan Pustaka}

\section{Penelitian Terdahulu}

Terdapat cukup banyak penelitian terdahulu mengenai pengukuran kinerja logistik dan manajemen rantai pasok dalam

\section{Volume 01, Nomor 01, April 2018}

hubungannya dengan peningkatan kinerja bisnis dan daya saing industri atau perusahaan.

Choy et.al (2007) mengembang-kan metode pengukuran kinerja dalam penerapan manajemen hubungan pemasok dengan pendekatan kerangka benchmarking rantai pasok dalam kegiatan pemeliharaan logistik. Pengukuran kinerja ini dapat membantu perusahaan dan pemasoknya dalam memahami kesenjangan kinerja, yang kemudian dapat ditentukan rantai pasok baru dan rencana strategis.

Tracey et al. (2005) meneliti kegiatan khusus rantai pasok dan menyelidiki dampaknya pada kinerja bisnis. Studi ini diperkuat oleh Mensah et al. (2014) yang menguji praktik manajemen rantai pasok dan dampaknya pada kinerja suatu perusahaan manufaktur di Ghana. Praktik manajemen rantai pasok secara signifikan mempengaruhi kinerja bisnis.

Brewer dan Speh (2000) menggunakan pendekatan Balanced Scorecard dalam mengukur kinerja rantai pasok, yang membantu dalam memanfaatkan rantai pasok menjadi sumber keunggulan kompetitif dan memberikan ide dalam mengatur rencana ke depannya. Saboia et.al. (2006) menggunakan Balanced Scorecard sebagai model pengukuran logistik internal dalam menyusun sistem kontrol yang strategik di lingkungan yang kompetitif.

Pohlen dan Coleman (2005) menggunakan economic value added dan Activity Based Costing (ABC) untuk mengevaluasi kinerja rantai pasok. Barnard (2006) dan Mutakin dan Hubeis (2011) menerapkan Supply Chain Operations Reference (SCOR) model. Anatan (2010) meneliti pengaruh implementasi praktik manajemen rantai pasok terhadap pencapaian keunggulan kompetitif dan kinerja rantai pasok. Studi ini berpedoman pada model penelitian Li et.al (2006) yang menunjukkan adanya keterkaitan antara praktik manajemen 
Cundo Harimurti, Model Peningkatan Kinerja Sistem Logistik Yang Efektif Dan Efisien...

rantai pasokan, keunggulan kompetitif, dan kinerja bisnis perusahaan.

Phuangchampee dan Baramichai (2010) mengukur daya saing industri-industri di Thailand menggunakan Logistics Scorecard model, yang dapat memberikan informasi bagaimana seharusnya industri meningkatkan kinerjanya untuk memperbaiki pola bisnisnya. Penelitian lebih mengukur pada kualitas proses rantai pasok dan logistik, bukan hanya sistem. Hasilnya berupa indeks daya saing berdasarkan KPI yang ditentukan dan dibandingkan antara satu industri dengan industri lainnya, sehingga memberikan usulan pedoman bagi peningkatan rasio kinerja daya saing logistik industri.

Primiana (2011) dalam penelitiannya menunjukkan bahwa kinerja logistik berperan penting dalam peningkatan daya saing terutama daya saing nasional. Dalam penelitian ini dirancang model pengukuran kinerja logistik bagi industri komponen otomotif Indonesia dalam rangka meningkatkan daya saing dalam menghadapi integrasi MEA. Digunakan perspektif Logistics Scorecard Phuangchampee dan Baramichai yang terdiri dari lima perspektif, yaitu strategi bisnis, kapasitas dan perencanaan kerja, efisiensi dan produktivitas logistik, teknologi informasi, dan kolaborasi rantai pasok.

\section{Logistik}

Menurut Gattorna dan Walters dalam bukunya Managing Supply Chain: A Strategic Perspective, logistik merupakan aspek manajemen strategis yang bertanggung jawab mengelola akuisisi, pergerakan dan penyimpanan bahan mentah, bahan setengah jadi, persediaan barang jadi dan informasi yang menyertainya dalam suatu organisasi dan saluran pemasarannya untuk memenuhi harapan pelanggan sehingga dapat mencapai target keuntungan perusahaan.

Kegiatan logistik dalam lingkup nasional meliputi proses perencanaan, implementasi, pengendalian efisiensi, aliran biaya yang efektif dan penyimpanan bahan mentah, bahan setengah jadi, barang jadi dan informasi-informasi yang menyertainya yang menjamin pengadaan dan ketersediaan komoditas strategis, dan meningkatkan daya saing industri (Mulyadi, 2011). Secara umum kegiatan logistik terdiri dari dua kegiatan yaitu kegiatan pergerakan (move) yang bersifat dinamis dan penyimpanan (store) yang bersifat statis.

Misi logistik adalah memenuhi kebutuhan barang yang sesuai ke tempat yang tepat, pada waktu yang tepat dan pada kondisi yang diinginkan, sehingga memberikan manfaat bagi perusahaan. (Gattorna, Walters, Bowersox, Closs, Toyota Production System). Dibutuhkan waktu yang lama bagi perusahaan untuk menyadari pentingnya logistik untuk mengembangkan keunggulan kompetitif terhadap pesaing. Setiap proses internal logistik harus dikendalikan dengan baik untuk mencapai daya saing tinggi (Saboia et.al., 2006).

\section{Sistem Logistik Terpadu}

Manajemen Logistik Terpadu merupakan suatu kegiatan manajemen logistik yang meliputi dua bidang yang berkaitan, yaitu: bidang organisasi logistik dan bidang koordinasi logistik. Bidang Operasi Logistik, merupakan kegiatan-kegiatan yang bersifat fisik. Manajemen distribusi fisik menyangkut masalah pengangkutan produk kepada langganan. Dalam distribusi fisik, langganan dipandang sebagai pemberhentian terakhir dalam saluran pemasaran. Manajemen material adalah menyangkut perolehan (procurement) dan pengangkutan material, suku cadang dan atau persediaan barang jadi dari tempat pembelian ke tempat pembuatan/perakitan gudang atau toko pengecer.

Proses transfer internal adalah mengenai pengawasan terhadap komponen-komponen setengah jadi pada waktu ia mengalir diantara tahap-tahap manufacturing dan pengangkutan awal dari produk jadi ke gudang atau ke saluran pengecer.

Bidang Koordinasi Logistik yang menyangkut pada kegiatan-kegiatan komunikasi dan perencanaan. Bidang ini meliputi identifikasi kebutuhan pergerakan dan penetapan rencana untuk memadukan 
JURNAL LOGISTIK INDONESIA

Majalah Ilmiah Institut STIAMI

ISSN 2579-8952

seluruh operasi logistik, antara lain: peramalan (forecasting), pengolahan pesanan (order processing), perencanaan operasi, perencanaan kebutuhan material (procurement).

\section{Pengukuran Kinerja Logistik}

SCM merupakan manajemen jaringan organisasi-organisasi dari hulu hingga hilir yang meliputi hubungan antar dua perusahaan atau lebih dan arus material, informasi dan sumber daya. Sedangkan logistik merupakan proses perencanaan, pelaksanaan, serta mengendalikan prosedur untuk transportasi dan penyimpanan barang secara efisien dan efektif (Sorooshian, 2013). Setiap perusahaan ingin mengetahui bagaimana performa dari kegiatan rantai pasok logistiknya, apakah telah mencapai tujuan. Oleh karena itu penting dilakukan pengukuran kinerja rantai pasok-logistik dan menerapkannya dengan baik.

Penelitian oleh Klapper et al. menghasilkan bahwa kinerja pelayanan logistik berpengaruh pada kepuasan pelanggan, yang memiliki hubungan dengan loyalitas pelanggan dan pangsa pasar. Kepuasan pelanggan tergantung pada kualitas pengelolaan arus barang dan jasa. Peranan jaringan distribusi dan manajemennya merupakan hal yang sangat penting untuk memenuhi permintaan konsumen sehingga meningkatkan penjualan dan keuntungan, agar dapat menghadapi integrasi pasar bebas MEA (Haryotejo, 2015).

\section{Logistics Scorecard Model}

SCM-Logistics Scorecard (LSC) telah dikembangkan sejak tahun 2001 oleh Tokyo Institute of Technology (Tokyo Tech) bekerjasama dengan Japan Institute of Logistics System (JILS). LSC telah menjadi alat yang efisien untuk menganalisis hubungan antara kinerja rantai pasokan perusahaan dan kinerja manajerialnya (Arashida et.al., 2004), menyelidiki korelasi antara lingkungan perusahaan dan pelaksanaan rantai pasok (Yaibuathet et.al., 2004), mengidentifikasi faktor-faktor
Volume 01, Nomor 01, April 2018

berpengaruh yang menentukan kinerja pelaksanaan manajamen rantai pasok dan dampaknya pada indeks keuangan bottom-line (Suzuki et.al., 2009), alat evaluasi kinerja operasional rantai pasokan perusahaan untuk mengetahui faktor-faktor potensial yang dapat meningkatkan efisiensi kinerja operasional rantai pasokan (Gong et.al., 2011).

Phuangchampee dan Baramichai (2010) menggunakan pendekatan model Logistics Scorecard untuk pengukuran kinerja manajemen rantai pasok-logistik industri di Thailand dalam rangka meningkatkan pola manajemennya agar lebih kompetitif. Pengukuran kinerja logistik ini tidak hanya mengukur sistem/proses bisnis rantai pasok tetapi juga kontrol kualitas dari proses itu sendiri. Pengukuran bersifat kualitatif untuk mengetahui pada posisi mana industri mengatur kegiatan bisnis mereka dan bagaimana rencana untuk mencapainya.

Indeks kunci daya saing diklasifikasikan bersama perspektif/aspek pengukuran kinerja logistik, yaitu: orientasi strategi bisnis, perencanaan kapasitas dan pelaksanaan, efisiensi dan produktivitas logistik, implementasi teknologi informasi, dan kolaborasi rantai pasok. Pengukuran lima perspektif dengan 23 KPI dirancang untuk menggambarkan fakta, angka serta respon kualitatif tentang praktek rantai pasok dalam organisasi. Respon kuantitatif diukur dengan penilaian skala atau level 1-5. Level 1 menunjukkan proses bisnis yang sangat buruk pada kinerja dan kemampuan logistik perusahaan, dan level 5 menunjukkan bahwa bisnis melakukan yang terbaik dalam kegiatan logistik.

\section{Perencanaan Strategi}

Perencanaan strategi dilakukan dimulai dari identifikasi pernyataan visi dan misi organisasi, analisa lingkungan internal dan eksternal organisasi, menentukan peluang dan ancaman/tantangan (faktor eksternal) serta kekuatan dan kelemahan (faktor internal). Kemudian, dengan menggunakan SWOT, kekuatan organisasi, kelemahan, peluang dan 
Cundo Harimurti, Model Peningkatan Kinerja Sistem Logistik Yang Efektif Dan Efisien...

ancaman dievaluasi. Hal ini berguna sebagai alat untuk menganalisa sistematis lingkungan internal dan eksternal organisasi dengan efektif, serta sebagai alat untuk mengidentifikasi masalah dan merencanakan tindakan masa depan (Hashemi et.al., 2012). Pembuatan peta strategi yang efektif akan membawa pada peningkatan sistem pengukuran kinerja, pelaksanan proses bisnis perusahaan menjadi lebih baik dan terbukti telah meningkatkan kinerja bagi banyak perusahaan (Armitage dan Scholey, 2006).

\section{Metodologi Penelitian}

Perancangan model pengukuran peningkatan kinerja logistik dibagi dalam dua tahap yaitu mengidentifikasi strategi bisnis rantai-pasok logistik nasional untuk mendapatkan indikator kinerja logistik yang sesuai dengan strategi logistiknya, serta menyusun model pengukuran kinerja logistik (Logistics Scorecard) dengan menggunakan indikator yang telah ditentukan. Identifikasi strategi bisnis logistik dimulai dengan identifikasi faktor internal dan faktor eksternal, analisa SWOT, hingga membuat peta strategi. Penyusunan model pengukuran peningkatan kinerja logistik dilakukan berdasarkan lima perspektif Logistics Scorecard. 


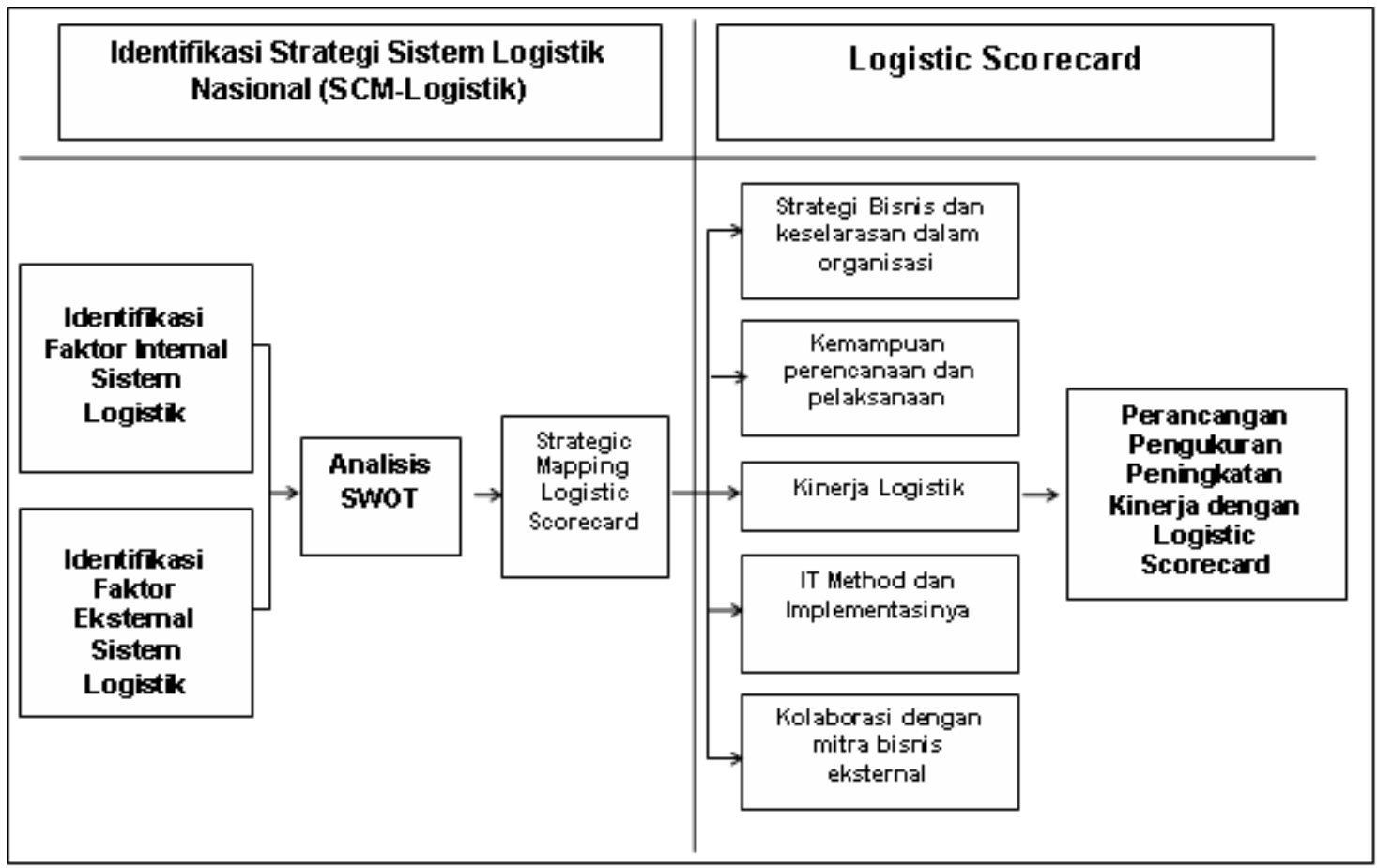

\section{Gambar 1}

Kerangka Pemikiran Perancangan Model Pengukuran Peningkatan Kinerja Sistem Logistik Nasional

\section{Tujuan Penelitian}

Tujuan penelitian ini adalah merancang suatu model pengukuran peningkatan kinerja sistem logistik yang efektif dan efisien untuk menguatkan daya saing nasional.

Model pengukuran ini dapat menjadi pedoman bagi peningkatan indikator-indikator kinerja sistem logistik.

\section{Analisis Sistem}

Analisis sistem yang dilakukan terdiri dari analisis situasi kondisi, analisis masalah dan identifikasi sistem. Analisis sistem diawali dengan pengumpulan data untuk memperoleh berbagai data yang berguna sebagai informasi untuk menganalisis situasi kondisi dan memenuhi kebutuhan dalam penelitian. Data diperoleh dari hasil wawancara dengan pihak-pihak yang terkait.

Penelitian mengambil studi kasus di salah satu perusahaan komponen otomotif anggota PIKKO. Data yang dikumpulkan antara lain situasi kondisi yang dihadapi industri komponen otomotif dalam MEA, peluang dan tantangan industri dalam menghadapi MEA, gambaran kegiatan bisnis perusahaan komponen otomotif khususnya kegiatan logistiknya, persiapan perusahaan mengenai MEA, serta profil dan karakteristik perusahaan komponen otomotif.

Model pengukuran yang dirancang akan dapat digunakan untuk mengukur peningkatan kinerja sistem logistik bagi industri komponen otomotif baik berskala industri kecil-menengah kepemilikan lokal maupun skala industri besar kepemilikan asing, serta lembaga atau institusi yang menaungi, misalnya: Kementerian Perindustrian dan PIKKO -, untuk dapat diambil kebijakan yang mendukung kegiatan bisnis perusahaan komponen otomotif.

Yang bertanggung jawab dalam melakukan pengukuran merupakan departemen terkait yaitu logistik atau manajemen rantai pasok, produksi, PPIC, 
Cundo Harimurti, Model Peningkatan Kinerja Sistem Logistik Yang Efektif Dan Efisien...

warehouse, baik secara tim maupun terpusat, baik kepala departemen maupun manajer dan direktur.

Dalam merancang model pengukuran kinerja logistik diperlukan indikator-indikator yang akan diukur dari kegiatan logistik yang dijalankan oleh perusahaan komponen otomotif. Akan tetapi indikator yang diperlukan ini belum terdefinisikan dengan jelas, bagaimanakah indikator kinerja logistik yang penting untuk peningkatan daya saing menghadapi MEA. Selain itu diperlukan juga target atau standar kinerja logistik yang diharapkan tercapai untuk berdaya saing dalam MEA, sistem pengukuran peningkatan kinerja, perhitungan nilai kinerja, serta pengkategorian nilai kinerja untuk mempermudah penggunaan model sehingga tercapai tujuan dari pengukuran.

Dalam melakukan pengukuran peningkatan kinerja sistem logistik dengan model yang dirancang, diperlukan input berupa kondisi kegiatan logistik perusahaan yang dicapai untuk setiap KPI. Penilaian ini bersifat kualitatif, oleh karena itu perlu dikuantitatifkan dengan menggunakan nilai skala yang ditentukan. Bobot bagi KPI perlu ditentukan untuk dapat memperoleh output berupa skor kinerja logistik bagi tiap KPI maupun skor akhir kinerja keseluruhan. Skor kinerja ini akan dikategorikan untuk melihat bagaimana posisi kinerja perusahaan terhadap perusahaan sejenis lain.

\section{Perancangan Model}

Perancangan model pengukuran peningkatan kinerja logistik dibagi dalam dua tahap yaitu (i) mengidentifikasi strategi bisnis logistik perusahaan komponen otomotif untuk mendapatkan indikator kinerja logistik yang sesuai dengan strategi logistik, (ii) menyusun model pengukuran kinerja logistik (Logistics Scorecard) dengan menggunakan indikator yang telah ditentukan.

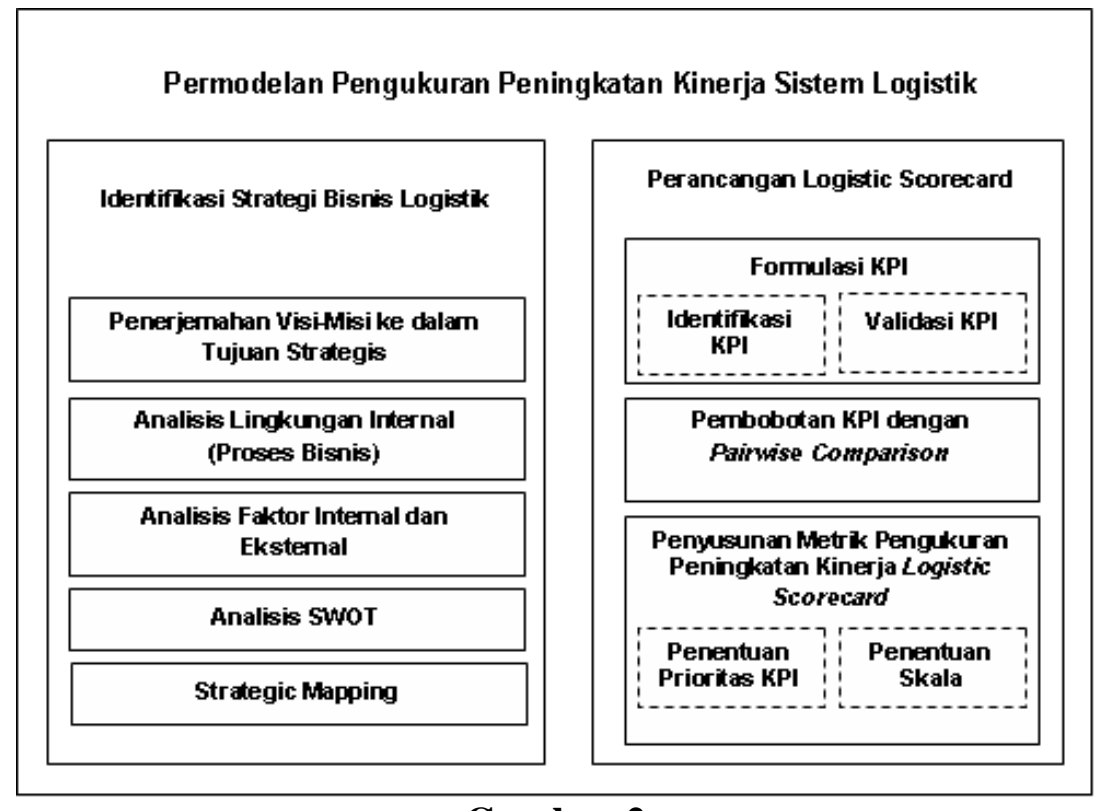

Gambar 2

Perancangan Model Pengukuran Kinerja Logistik 
Majalah Ilmiah Institut STIAMI

ISSN 2579-8952

\section{Identifikasi Strategi Bisnis}

Perencanaan strategi dilakukan dimulai dari identifikasi pernyataan visi dan misi perusahaan, analisa lingkungan internal dan

\section{Strength (S)}

1. Mempunyai produk unik, berkualitas, dan kompetitif

2. Diberikannya pelatihan-pelatihan untuk karyawan baik internal maupun eksternal

3. Keunggulan dalam memasok produk terpercaya oleh pabrikan otomotif besar

4. Ketepatan pemenuhan kuantitas pesanan

5. Produk tersebar pada tingkat after market

6. Kepemilikan perusahaan oleh pengusaha lokal, sehingga profit seluruhnya untuk lokal

7. Terjalin kerjasama baik dengan pemasok dan pelanggan eksternal perusahaan, menentukan peluang dan ancaman (faktor eksternal) serta kekuatan dan kelemahan (faktor internal).

\section{Opportunities (O)}

1. Adanya pasar bebas ASEAN membukan dan membentuk pasar yang lebih besar baik kawasan maupun global

2. Adanya kesempatan penawaran kerjasama dengan Jepang, Malaysia, Filipina, Thailand, Vietnam, dan negara lainnya

3. Kesempatan untuk melakukan ekspor produk/material ke negara lain, khususnya ASEAN

4. Tersedianya tenaga kerja yang lebih kompeten dan terampil akibat arus bebas tenaga kerja

5. Pengembangan teknologi (transfer teknologi)

6. Penambahan investasi dan modal dari asing.

7. Kondisi pasar bebas mendorong produksi dan distribusi barang berkualitas secara lebih efisien agar mampu bersaing

\begin{tabular}{|l|l}
\hline Weakness $(\mathbf{W})$ & Treats $(\mathbf{T})$
\end{tabular}

1. Material masih banyak yang ekspor

1. Adanya arus bebas barang dimana banyak produk luar masuk sehingga persaingan menjadi lebih ketat

2. Sebagian besar pekerja lulusan di bawah sarjana, dan tidak ada persyaratan ketat dalam proses rekrutmen

3. Keterbatasan jumlah pekerja

4. Tidak ada KPI untuk penilaian jenjang karir karyawan

5. Lokasi perusahaan kurang strategis

6. Keterbatasan kapasitas produksi

2. Nilai mata uang US\$ yang rentan dan tidak stabil dapat berpengaruh terhadap meningkatnya cost material impor

3. Masuknya material/produk luar dengan harga lebih murah

4. Besarnya biaya pajak karena meningkatnya produksi

5. Produk competitor menawarkan kualitas dan desain lebih bagus dan menarik

6. Tuntutan untuk memenuhi target permintaan konsumen karena pasar 
Cundo Harimurti, Model Peningkatan Kinerja Sistem Logistik Yang Efektif Dan Efisien...

7. Keterbatasan kapasitas gudang

8. Keterbatasan teknologi informasi dan teknologi mesin

9. Alur struktur organisasi yang kurang baik

10. Belum ada departemen logistik mandiri

11. Lingkungan kerja yang belum tertata dengan baik, rapih, dan nyaman

12. Implementasi strategi sehingga level fungsional masih rendah

yang lebih besar

7. Arus informasi yang terintegrasi menuntut selalu update informasi dalam pengembangan teknologi

8. Penurunan pangsa pasar karena persaingan lebih besar

9. Tuntutan standarisasi dan sertifikasi perusahaan maupun tenaga kerja

10. Upah tenaga kerja yang semakin tinggi namun tidak diikuti dengan peningkatan produktivitas

11. Suku bunga tinggi dan tingginya biaya investasi

12. Ketidakstabilan sumber energi

13. Adanya kesamaan jenis produk baik dari ekspor maupun produk impor

\section{Gambar 3}

\section{Analisa Faktor Internal dan Eksternal Perusahaan}

Kemudian, dengan menggunakan SWOT, kekuatan organisasi, kelemahan, peluang dan ancaman dievaluasi.

Selanjutnya dilakukan perumusan strategi ke dalam lima perspektif Logistics Scorecard dan disusun Logistics Scorecard Strategy Map yang menggambarkan keterkaitan antara tiap strategi.

\section{Strategi SO}

1. Kerjasama pengembangan logistik dengan partner bisnis lain ( $\mathrm{S} 3, \mathrm{~S} 7, \mathrm{O} 2$, $\mathrm{O}, 5, \mathrm{O6}, \mathrm{O} 7$ )

2. Menetapkan perjanjian kontrak dan pertukaran informasi yang jelas dengan pemasok (S1, S3, S7, O2)

3. Penurunan lead time pelanggan ( $\mathrm{S} 4$, $\mathrm{S} 7, \mathrm{O} 1, \mathrm{O} 7$ )

4. Peningkatan sistem perbaikan kepuasan pelanggan (S4, S7, O1, O3, O7)

5. Peningkatan pemahaman trend pasar dan forecast permintaan (S3, S4, S5, $\mathrm{O} 1, \mathrm{O} 3$ )

6. Menetapkan perjanjian kontrak dan pertukaran informasi yang jelas dengan pelanggan (S1, S3, S5, O1, O3)

\section{Strategi WO}

1. Pengembangan logistik dengan bantuan sarjana, lembaga, dll (W2, W8, W10, O1, O4, O7)

2. Pengembangan departemen logistik untuk pengiriman barang lebih baik (W10, O3, O7)

3. Pengembangan akses informasi kontrak dengan pelanggan dan informasi lainnya (W8, O1, O7)

4. Perbaikan kegiatan logistik perusahaan (W2, W7, W9, W10, O1, O3, 6)

5. Pengembangan karyawan, khususnya di bidang Teknologi Informasi dan Logistik (W2, W3, W8, W9, W10, W12, O3, O4, O5)

6. Adanya standar pengidentifikasian (kode) untuk seluruh produk maupun proses (W8, W, 9, W12, O 1, O3, O5, 
Majalah Ilmiah Institut STIAMI

ISSN 2579-8952

\begin{tabular}{|c|c|c|}
\hline & $\begin{array}{l}\text { Perbaikan kegiatan logistik (S1, S4, } \\
\mathrm{S} 7, \mathrm{O} 1, \mathrm{O} 2, \mathrm{O} 3)\end{array}$ & $\begin{array}{ll}\text { 7. } & \begin{array}{l}\text { O7) } \\
\text { Pembuatan strategi yang } \\
\text { mengoptimalkan sumber daya logistik } \\
\text { perusahaan (W9, 10, W12, O1, O3, }\end{array} \\
\text { O5, 6) } \\
\text { 8. }\end{array}$ \\
\hline \multicolumn{2}{|c|}{ Strategi ST } & Strategi WT \\
\hline & $\begin{array}{l}\text { Membuat strategi bisnis yang tepat, } \\
\text { khususnya di bidang logistik (S1, S4, } \\
\text { S5, S7, T3, T5, T6) }\end{array}$ & $\begin{array}{l}\text { 1. Peningkatan lingkungan kerja yang } \\
\text { kondusif (ISO 14000) (W11, T1, T4) }\end{array}$ \\
\hline & $\begin{array}{l}\text { Peningkatan kinerja dan kualitas } \\
\text { pengiriman produk }(\mathrm{S} 3, \mathrm{~S} 4, \mathrm{~S} 5, \mathrm{~T} 2, \\
\mathrm{T} 6, \mathrm{~T} 8, \mathrm{~T} 12)\end{array}$ & $\begin{array}{l}\text { 2. Sistem manajemen persediaan yang } \\
\text { baik (W6, W7, W10, T6) }\end{array}$ \\
\hline & $\begin{array}{l}\text { Penurunan total biaya logistik (S3, S5, } \\
\text { S6, S7, T2, T3, T4, T10, T11) }\end{array}$ & $\begin{array}{l}\text { 3. Peningkatan sistem monitoring dan } \\
\text { tracking persediaan (W6, W7, W8, T6, } \\
\text { T7, T8) }\end{array}$ \\
\hline & $\begin{array}{l}\text { Peningkatan sistem pelatihan pekerja } \\
\text { dan evaluasi (S2, T1, T6, T7, T9, T10) }\end{array}$ & $\begin{array}{l}\text { 4. Peningkatan efektivitas penggunakan } \\
\text { komputer dalam seluruh kegiatan } \\
\text { bisnis perusahaan (W2, W8, W12, T1, } \\
\text { T7) }\end{array}$ \\
\hline 5 . & $\begin{array}{l}\text { Peningkatan perputaran persediaan dan } \\
\text { cash-to-cash cycle time perusahaan } \\
(\mathrm{S} 6, \mathrm{~T} 2, \mathrm{~T} 3, \mathrm{~T} 4, \mathrm{~T} 11)\end{array}$ & $\begin{array}{l}\text { 5. Peningkatan kemampuan perencanaan } \\
\text { SCM-Logistik (W2, W9, W10, W12, } \\
\text { T1, T6, T13) }\end{array}$ \\
\hline & $\begin{array}{l}\text { Pembuatan strategi yang } \\
\text { mengoptimalkan sumber daya logistik } \\
\text { perusahaan (S1, S2, S3, S7, T2, T3, } \\
\text { T4, T10, T12) }\end{array}$ & $\begin{array}{l}\text { 6. Peningkatan sistem training pekerja } \\
\text { (W2, W9, T5, T6, T7, T9, T10, T13) }\end{array}$ \\
\hline & $\begin{array}{l}\text { Sistem manajemen persediaan yang } \\
\text { baik (S3, S5, S7, T6) }\end{array}$ & $\begin{array}{l}\text { 7. Pengembangan karyawan khususnya di } \\
\text { bidang Teknologi Informasi dan } \\
\text { Logistik (W2, W3, W8, W10, W12, } \\
\text { T5, T6, T7, T9, T10) }\end{array}$ \\
\hline & $\begin{array}{l}\text { Peningkatan pemahaman trend pasar } \\
\text { dan forecast permintaan ( } 33, \mathrm{~S} 4, \mathrm{~S} 5 \text {, } \\
\mathrm{T} 1, \mathrm{~T} 3, \mathrm{~T} 5, \mathrm{~T} 6, \mathrm{~T} 8, \mathrm{~T} 13)\end{array}$ & $\begin{array}{l}\text { 8. Menetapkan standarisasi di seluruh } \\
\text { proses bisnis (W2, W9, W12, T1, T5, } \\
\text { T9) }\end{array}$ \\
\hline
\end{tabular}

\section{Gambar 4 \\ Analisa SWOT}

Penelitian ini mengambil studi kasus salah satu perusahaan komponen otomotif yang tergabung dalam Perkumpulan Industri Kecil-Menengah Komponen Otomotif Indonesia (PIKKO), yaitu PT. ABC.

\section{Perancangan Logistics Scorecard}

\subsection{Penentuan KPI Logistik Berdasarkan Perspektif Logistics Scorecard}

Dilakukan identifikasi indikator kinerja berdasarkan strategi yang telah disusun untuk mencapai tujuan yaitu melaksanakan kegiatan proses bisnis logistik yang berdaya saing untuk 
Cundo Harimurti, Model Peningkatan Kinerja Sistem Logistik Yang Efektif Dan Efisien...

menghadapi pasar bebas MEA. Ditentukan indikator kinerja beserta targetnya untuk setiap strategi yang telah dikelompokkan dalam perspektif Logistics
Scorecard. Contoh untuk perspektif orientasi strategi bisnis dapat dilihat pada Tabel 1.

Tabel 1

Strategi, Indikator Kinerja, dan Target

\begin{tabular}{|l|l|l|}
\hline \multicolumn{1}{|c|}{ Strategi } & Indikator Kinerja & \multicolumn{1}{c|}{ Target } \\
\hline \multicolumn{2}{|c|}{ Perspektif Orientasi Strategi Bisnis } \\
\hline $\begin{array}{l}\text { Membuat strategi } \\
\text { bisnis logistik yang } \\
\text { tepat }\end{array}$ & $\begin{array}{l}\text { Srategi bisnis } \\
\text { logistik }\end{array}$ & $\begin{array}{l}\text { Strategi bisnis yang tepat, jelas dan } \\
\text { terdapat sistem yang mendukung } \\
\text { kegiatan SCM-Logistik }\end{array}$ \\
\hline $\begin{array}{l}\text { Menetapkan perjanjian } \\
\text { kontrak dan pertukaran } \\
\text { informasi yang jelas } \\
\text { dengan pemasok }\end{array}$ & $\begin{array}{l}\text { Perjanjian kontrak } \\
\text { dan pertukaran } \\
\text { informasi dengan } \\
\text { pemasok }\end{array}$ & $\begin{array}{l}\text { Terdapat perjanjian tertulis yang formal } \\
\text { dengan seluruh pemasok, kegiatan } \\
\text { sharing, dan rencana pengembangan } \\
\text { pemasok yang mapan }\end{array}$ \\
\hline $\begin{array}{l}\text { Menetapkan perjanjian } \\
\text { kontrak dan pertukaran } \\
\text { informasi yang jelas } \\
\text { dengan pelanggan }\end{array}$ & $\begin{array}{l}\text { Perjanjian kontrak } \\
\text { dan pertukaran } \\
\text { informasi dengan } \\
\text { pelanggan }\end{array}$ & $\begin{array}{l}\text { Terdapat perjanjian tertulis yang formal } \\
\text { dengan selunuh pelanggan, kegiatan } \\
\text { sharing, dan rencana pengembangan } \\
\text { pelanggan yang mapan }\end{array}$ \\
\hline $\begin{array}{l}\text { Peningkatan sistem } \\
\text { perbaikan kepuasan } \\
\text { pelanggan }\end{array}$ & $\begin{array}{l}\text { Sistem pengukuran } \\
\text { dan perbaikan } \\
\text { kepuasan pelanggan }\end{array}$ & $\begin{array}{l}\text { Peningkatan sistem pengukuran dan } \\
\text { perbaikan kepuasan pelanggan, yang } \\
\text { hasilnya digunakan untuk } \\
\text { pengembangan produk dan pelayanan }\end{array}$ \\
\hline $\begin{array}{l}\text { Peningkatan sistem } \\
\text { training pekerja dan } \\
\text { evaluasi }\end{array}$ & $\begin{array}{l}\text { Sistem training } \\
\text { pekerja dan } \\
\text { evaluasinya }\end{array}$ & $\begin{array}{l}\text { Peningkatan sistem training dan } \\
\text { evaluasi pekerja, terdapat sistem } \\
\text { manajemen pengetahuan untuk sharing } \\
\text { pengetahuan }\end{array}$ \\
\hline
\end{tabular}

Indikator kinerja tersebut perlu divalidasi apakah sesuai untuk dijadikan sebagai indikator dalam pengukuran kinerja logistik industri komponen otomotif. Digunakan teknik Delphi dengan lima pakar yang merupakan Direktur PT. ABC, Kepala Departemen Warehouse \& Logistik PT. ABC, pihak akademisi expert di bidang rantai pasok-logistik, pihak praktisi komponen otomotif lain, serta pihak praktisi otomotif yaitu dari distributor/ATPM. Setiap responden diberikan proporsi berbeda dilihat dari tingkat kepentingan dan pengaruhnya terhadap penentuan kinerja logistik PT. ABC. Hasil rangkuman dari teknik Delphi diperoleh komposisi jawaban kelima responden memberikan penilaian sama untuk indikator diperlukan semuanya lebih dari $60 \%$ (Eadie, R. et.al., 2010) dan dapat dikatakan sudah mencapai konsensus. Semua indikator diperlukan dalam pengukuran kinerja logistik perusahaan komponen otomotif dikarenakan indikator-indikator tersebut dapat menunjukkan secara detail bagaimana aktivitas kegiatan proses bisnis rantai pasoklogistik perusahaan.

$$
\text { Selanjutnya dilakukan }
$$
penyusunan KPI logistik dalam bentuk hierarki untuk mempermudah dalam melihat gambaran model pengukuran peningkatan kinerja logistik berdasarkan perspektif Logistics Scorecard. 



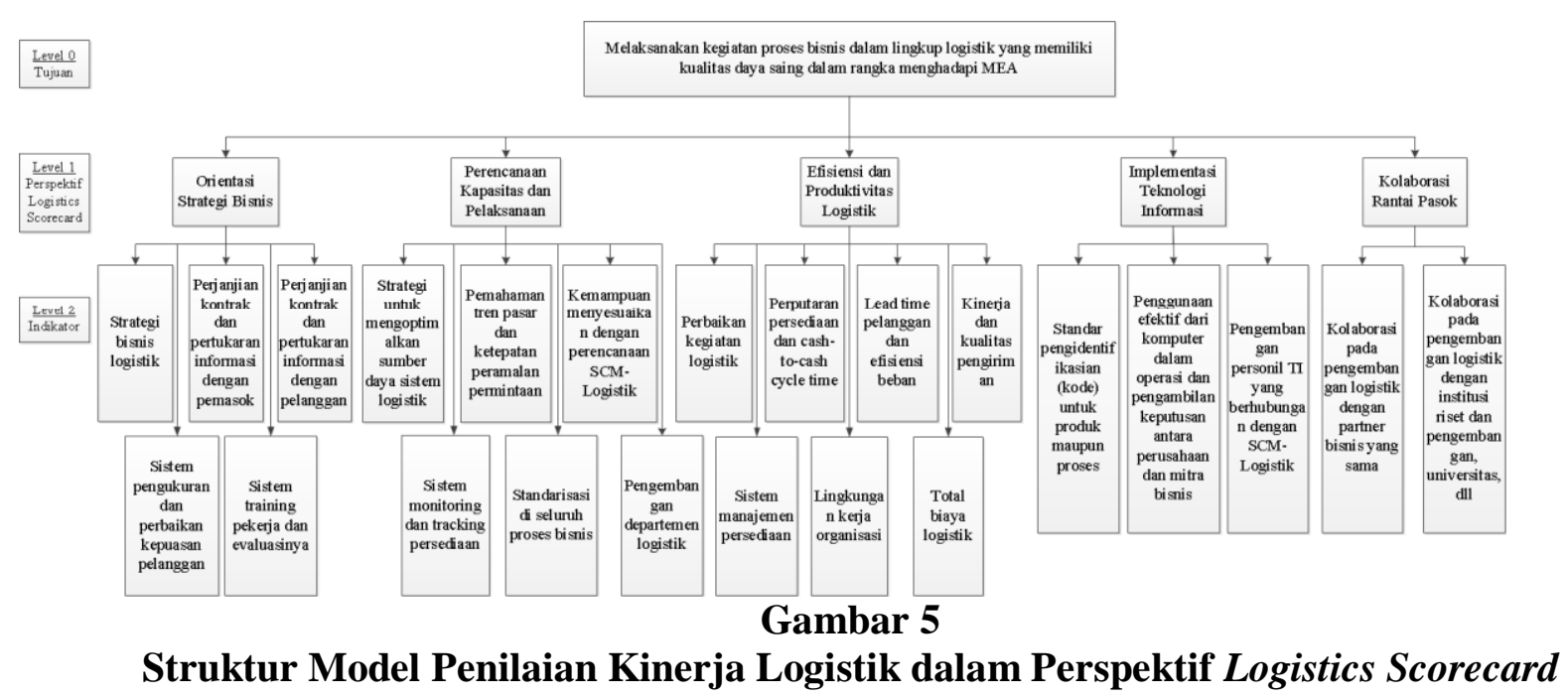

\subsection{Pembobotan KPI Logistik}

Pembobotan KPI logistik berdasarkan pandangan para pakar dengan melakukan pengisian kuesioner pairwise comparison (perbandingan berpasangan). Beberapa tahapan yang dilakukan antara lain penerjemahan matriks perbandingan berpasangan ke dalam angka desimal, uji konsistensi pakar, penyatuan hasil kuesioner pairwise comparison para pakar dengan menggunakan perhitungan rata-rata geometrik, hingga penentuan bobot. Perbandingan berpasangan dilakukan antar perspektif Logistics Scorecard dan antar indikator dalam setiap perspektif. Para pakar yang dipilih untuk melakukan penilaian ini adalah praktisi di perusahaan komponen otomotif, yaitu Direktur dan Kepala Departemen Warehouse \& Logistik PT. ABC, serta pihak akademis expert di bidang rantai pasok-logistik.

Hasil pembobotan diperoleh perspektif kinerja logistik yang memiliki bobot tertinggi adalah perspektif orientasi strategi bisnis. Para pakar berpendapat bahwa perspektif paling penting dalam pengukuran peningkatan kinerja logistik bagi industri komponen otomotif di Indonesia adalah orientasi strategi bisnis yang harus diprioritaskan dalam upaya peningkatan kinerja logistik bagi perusahaan komponen otomotif agar memiliki daya saing tinggi. Berada pada prioritas kedua adalah perspektif perencanaan kapasitas dan pelaksanaan, kolaborasi rantai pasok, efisiensi dan produktivitas logistik, dan implementasi teknologi informasi.

\subsection{Penyusunan Metrik Pengukuran Peningkatan Kinerja Logistik}

Dilakukan penentuan prioritas KPI dan penentuan skala pengukuran kinerja. Kemudian disusun metrik pengukuran kinerja Logistics Scorecard dengan kolom pengisian yang disediakan. Penentuan prioritas KPI dilakukan dengan mengurutkan bobot akhir setiap KPI dari yang paling tinggi. Bobot akhir diperoleh dengan mengalikan bobot setiap KPI dengan bobot perspektif dimana KPI tersebut dikelompokkan. Gambar 6 menampilkan prioritas KPI berdasarkan bobotnya.

Skala penilaian menggunakan tipe skala descriptive graphic rating scale, dengan skala 1 sampai 5. Untuk setiap KPI didefinisikan bagaimana level terendahnya, yang diwakilkan oleh skala 1, hingga bagaimana level tertingginya, yang diwakilkan oleh skala 5. Contoh penulisan skala pengukuran dapat dilihat pada Tabel 2. 
Cundo Harimurti, Model Peningkatan Kinerja Sistem Logistik Yang Efektif Dan Efisien...

\begin{tabular}{|c|c|c|c|c|c|c|c|c|}
\hline \multicolumn{6}{|c|}{ Bobot Akhir KPI } & \multicolumn{3}{|c|}{ Prioritas KPI } \\
\hline $\begin{array}{l}\text { Persp } \\
\text { ektif }\end{array}$ & $\begin{array}{l}\text { Bobo } \\
\text { t } \\
\text { Pers } \\
\text { pekti } \\
\text { f }\end{array}$ & $\begin{array}{l}\text { Ko } \\
\text { de }\end{array}$ & Kriteria & $\begin{array}{l}\text { Bo } \\
\text { bot } \\
\text { Kri } \\
\text { teri } \\
\text { a }\end{array}$ & $\begin{array}{c}\text { Bo } \\
\text { bo } \\
\text { t } \\
\text { Ak } \\
\text { hir }\end{array}$ & $\begin{array}{l}\text { Ko } \\
\text { de }\end{array}$ & Kriteria & $\begin{array}{c}\text { Bo } \\
\text { bo } \\
\text { t }\end{array}$ \\
\hline \multirow{5}{*}{$\begin{array}{l}\text { Orien } \\
\text { tasi } \\
\text { Strat } \\
\text { egi } \\
\text { Bisni } \\
\text { S }\end{array}$} & \multirow{5}{*}{0.43} & $\begin{array}{l}\text { BS } \\
01\end{array}$ & $\begin{array}{ll}\text { Strategi } & \text { bisnis } \\
\text { logistik }\end{array}$ & $\begin{array}{c}0.4 \\
6\end{array}$ & $\begin{array}{c}0.1 \\
98 \\
4\end{array}$ & $\begin{array}{l}\text { BS } \\
01\end{array}$ & $\begin{array}{ll}\text { Strategi } & \text { bisnis } \\
\text { logistik }\end{array}$ & $\begin{array}{l}0.1 \\
98 \\
4\end{array}$ \\
\hline & & $\begin{array}{l}\text { BS } \\
02\end{array}$ & $\begin{array}{l}\text { Perjanjian } \\
\text { kontrak dan } \\
\text { pertukaran } \\
\text { informasi dengan } \\
\text { pemasok }\end{array}$ & $\begin{array}{c}0.0 \\
7\end{array}$ & $\begin{array}{c}0.0 \\
28 \\
1\end{array}$ & $\begin{array}{l}\mathrm{SC} \\
\mathrm{CI}\end{array}$ & $\begin{array}{l}\text { Kolaborasi pada } \\
\text { pengembanan } \\
\text { logistik dengan } \\
\text { partner bisnis } \\
\text { yang sama }\end{array}$ & $\begin{array}{l}0.1 \\
07 \\
2\end{array}$ \\
\hline & & $\begin{array}{l}\text { BS } \\
03\end{array}$ & $\begin{array}{l}\text { Perjanjian } \\
\text { kontrak dan } \\
\text { pertukaran } \\
\text { informasi dengan } \\
\text { pelanggan }\end{array}$ & $\begin{array}{c}0.0 \\
8\end{array}$ & $\begin{array}{c}0.0 \\
35 \\
2\end{array}$ & $\begin{array}{l}\text { BS } \\
04\end{array}$ & $\begin{array}{l}\text { Sistem } \\
\text { pengukuran dan } \\
\text { perbaikan } \\
\text { kepuasan } \\
\text { pelanggan }\end{array}$ & $\begin{array}{l}0.1 \\
04 \\
2\end{array}$ \\
\hline & & $\begin{array}{l}\text { BS } \\
04\end{array}$ & $\begin{array}{l}\text { Sistem } \\
\text { pengukuran dan } \\
\text { perbaikan } \\
\text { kepuasan } \\
\text { pelanggan }\end{array}$ & $\begin{array}{c}0.2 \\
4\end{array}$ & $\begin{array}{c}0.1 \\
04 \\
2\end{array}$ & $\begin{array}{l}\mathrm{C} \\
\mathrm{W} \\
\mathrm{P} 1\end{array}$ & $\begin{array}{l}\text { Strategi untuk } \\
\text { mengoptimalkan } \\
\text { sumber daya } \\
\text { sistem logistik }\end{array}$ & $\begin{array}{l}0.0 \\
86 \\
7\end{array}$ \\
\hline & & $\begin{array}{l}\mathrm{BS} \\
05\end{array}$ & $\begin{array}{l}\text { Sistem training } \\
\text { pekerja dan } \\
\text { evaluasinya }\end{array}$ & $\begin{array}{c}0.1 \\
5\end{array}$ & $\begin{array}{c}0.0 \\
64 \\
4 \\
\end{array}$ & $\begin{array}{l}\text { BS } \\
05\end{array}$ & $\begin{array}{lr}\text { Sistem training } \\
\text { pekerja } \\
\text { evaluasinya }\end{array}$ & $\begin{array}{l}0.0 \\
64 \\
4 \\
\end{array}$ \\
\hline \multirow{5}{*}{$\begin{array}{l}\text { Peren } \\
\text { canaa } \\
\text { n } \\
\text { kapas } \\
\text { itas } \\
\text { dan } \\
\text { pelak } \\
\text { sanaa } \\
\text { n }\end{array}$} & \multirow{5}{*}{0.27} & $\begin{array}{l}\mathrm{CP} \\
\mathrm{W} \\
1\end{array}$ & $\begin{array}{l}\text { Strategi untuk } \\
\text { mengoptimalkan } \\
\text { sumber daya } \\
\text { sistem logistik }\end{array}$ & $\begin{array}{c}0.3 \\
3\end{array}$ & $\begin{array}{c}0.0 \\
86 \\
7\end{array}$ & $\begin{array}{l}\mathrm{CP} \\
\mathrm{W} \\
5\end{array}$ & $\begin{array}{l}\text { Standarisasi } \\
\text { seluruh proses } \\
\text { bisnis }\end{array}$ & $\begin{array}{l}0.0 \\
54 \\
1\end{array}$ \\
\hline & & $\begin{array}{l}\mathrm{CP} \\
\mathrm{W} \\
2\end{array}$ & $\begin{array}{l}\text { Pemahaman } \\
\text { trend pasar dan } \\
\text { ketepatan } \\
\text { peramalan } \\
\text { permintaan }\end{array}$ & $\begin{array}{c}0.1 \\
8\end{array}$ & $\begin{array}{c}0.0 \\
48 \\
3\end{array}$ & $\begin{array}{l}\mathrm{SC} \\
\mathrm{C} 2\end{array}$ & $\begin{array}{l}\text { Kolaborasi pada } \\
\text { pengembangan } \\
\text { logistik dengan } \\
\text { institusi riset dan } \\
\text { pengembangan, } \\
\text { universitas, dll }\end{array}$ & $\begin{array}{l}0.0 \\
52 \\
9\end{array}$ \\
\hline & & $\begin{array}{l}\mathrm{CP} \\
\mathrm{W} \\
3\end{array}$ & $\begin{array}{l}\text { Kemampuan } \\
\text { menyesuaikan } \\
\text { dnegan } \\
\text { perencanaan } \\
\text { SCM-Logistik }\end{array}$ & $\begin{array}{c}0.1 \\
7\end{array}$ & $\begin{array}{c}0.0 \\
46 \\
0\end{array}$ & $\begin{array}{l}\mathrm{CP} \\
\mathrm{W} \\
2\end{array}$ & $\begin{array}{l}\text { Pemahaman } \\
\text { trend pasar dan } \\
\text { ketepatan } \\
\text { peramalan } \\
\text { permintaan }\end{array}$ & $\begin{array}{l}0.0 \\
48 \\
3\end{array}$ \\
\hline & & $\begin{array}{l}\text { CP } \\
W \\
4\end{array}$ & $\begin{array}{l}\text { Sistem } \\
\text { monitoring dan } \\
\text { tracking } \\
\text { persediaan }\end{array}$ & $\begin{array}{c}0.0 \\
6\end{array}$ & $\begin{array}{c}0.0 \\
16 \\
8\end{array}$ & $\begin{array}{l}\mathrm{CP} \\
\mathrm{W} \\
3\end{array}$ & $\begin{array}{l}\text { Kemampuan } \\
\text { menyesuaikan } \\
\text { dnegan } \\
\text { perencanaan } \\
\text { SCM-Logistik }\end{array}$ & $\begin{array}{l}0.0 \\
46 \\
0\end{array}$ \\
\hline & & $\mathrm{CP}$ & Standarisasi & 0.2 & 0.0 & $\mathrm{BS}$ & Perjanjian & 0.0 \\
\hline
\end{tabular}


Majalah Ilmiah Institut STIAMI

ISSN 2579-8952

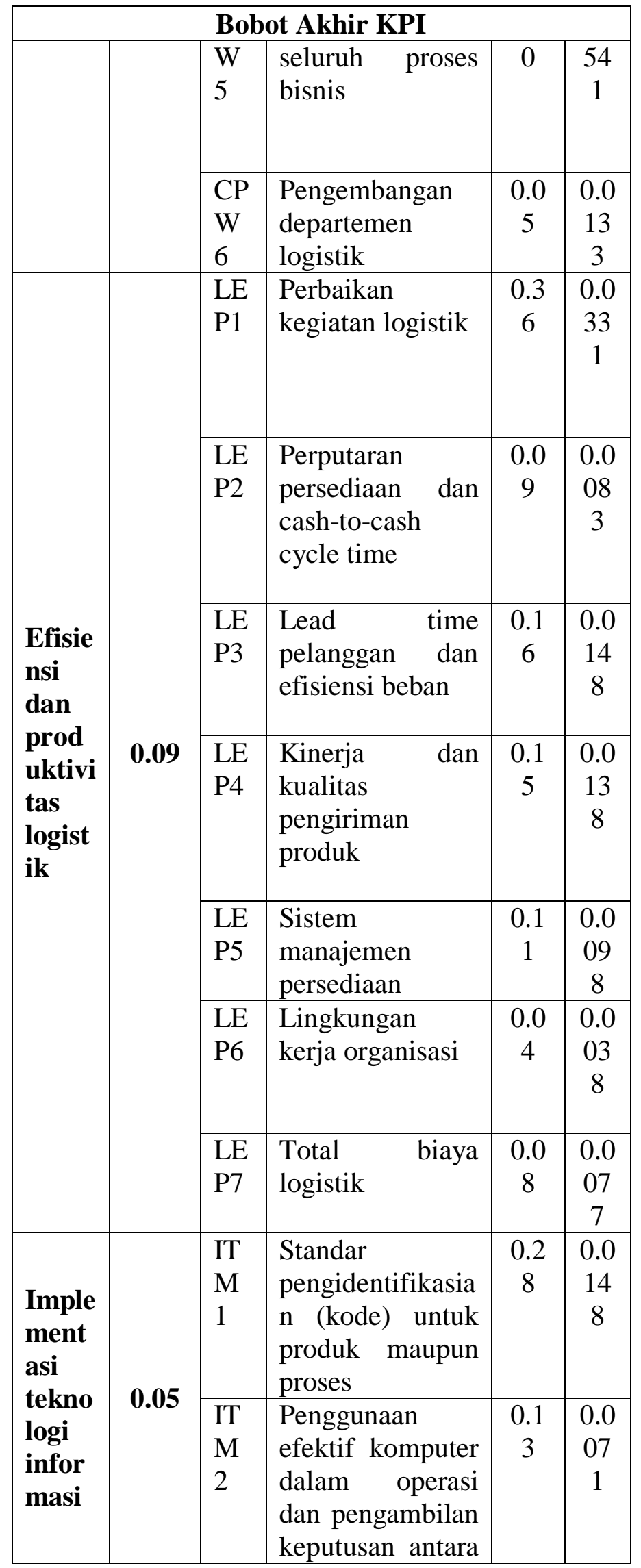

\begin{tabular}{|c|c|c|}
\hline \multicolumn{3}{|c|}{ Prioritas KPI } \\
\hline $\mathrm{O} 3$ & $\begin{array}{l}\text { kontrak dan } \\
\text { pertukaran } \\
\text { informasi dengan } \\
\text { pelanggan }\end{array}$ & $\begin{array}{l}35 \\
2\end{array}$ \\
\hline $\begin{array}{l}\text { LE } \\
\text { P1 }\end{array}$ & $\begin{array}{l}\text { Perbaikan } \\
\text { kegiatan logistik }\end{array}$ & $\begin{array}{l}0.0 \\
33 \\
1 \\
\end{array}$ \\
\hline $\begin{array}{l}\text { IT } \\
\text { M } \\
3\end{array}$ & $\begin{array}{l}\text { Pengembangan } \\
\text { personel TI yang } \\
\text { berhubungan } \\
\text { dengan SCM- } \\
\text { Logistik }\end{array}$ & $\begin{array}{l}0.0 \\
31 \\
2\end{array}$ \\
\hline $\begin{array}{l}\mathrm{BS} \\
\mathrm{O} 2\end{array}$ & $\begin{array}{l}\text { Perjanjian } \\
\text { kontrak dan } \\
\text { pertukaran } \\
\text { informasi dengan } \\
\text { pemasok }\end{array}$ & $\begin{array}{l}0.0 \\
28 \\
1\end{array}$ \\
\hline $\begin{array}{l}\text { CP } \\
W \\
4\end{array}$ & $\begin{array}{l}\text { Sistem } \\
\text { monitoring dan } \\
\text { tracking } \\
\text { persediaan }\end{array}$ & $\begin{array}{l}0.0 \\
16 \\
8\end{array}$ \\
\hline $\begin{array}{l}\mathrm{IT} \\
\mathrm{M} \\
1\end{array}$ & $\begin{array}{l}\text { Standar } \\
\text { pengidentifikasia } \\
\text { n (kode) untuk } \\
\text { produk maupun } \\
\text { proses }\end{array}$ & $\begin{array}{l}0.0 \\
14 \\
8\end{array}$ \\
\hline $\begin{array}{l}\text { LE } \\
\text { P3 }\end{array}$ & $\begin{array}{l}\text { Lead time } \\
\text { pelanggan dan } \\
\text { efisiensi beban }\end{array}$ & $\begin{array}{l}0.0 \\
14 \\
8 \\
\end{array}$ \\
\hline $\begin{array}{l}\text { LE } \\
\text { P4 }\end{array}$ & $\begin{array}{l}\text { Kinerja dan } \\
\text { kualitas } \\
\text { pengiriman } \\
\text { produk }\end{array}$ & $\begin{array}{l}0.0 \\
13 \\
8\end{array}$ \\
\hline $\begin{array}{l}\mathrm{CP} \\
\mathrm{W} \\
6 \\
\end{array}$ & $\begin{array}{l}\text { Pengembangan } \\
\text { departemen } \\
\text { logistik }\end{array}$ & $\begin{array}{l}0.0 \\
13 \\
3\end{array}$ \\
\hline $\begin{array}{l}\mathrm{LE} \\
\mathrm{P} 5\end{array}$ & $\begin{array}{l}\text { Sistem } \\
\text { manajemen } \\
\text { persediaan }\end{array}$ & $\begin{array}{l}0.0 \\
09 \\
8\end{array}$ \\
\hline $\begin{array}{l}\text { LE } \\
\text { P2 }\end{array}$ & $\begin{array}{l}\text { Perputaran } \\
\text { persediaan dan } \\
\text { cash-to-cash } \\
\text { cycle time }\end{array}$ & $\begin{array}{l}0.0 \\
08 \\
3\end{array}$ \\
\hline
\end{tabular}


Cundo Harimurti, Model Peningkatan Kinerja Sistem Logistik Yang Efektif Dan Efisien...

\begin{tabular}{|c|c|c|c|c|c|}
\hline \multicolumn{6}{|c|}{ Bobot Akhir KPI } \\
\hline & & & $\begin{array}{l}\text { perusahaan dan } \\
\text { mitra bisnis }\end{array}$ & & \\
\hline & & $\begin{array}{l}\text { IT } \\
\text { M } \\
3\end{array}$ & $\begin{array}{l}\text { Pengembangan } \\
\text { personel TI yang } \\
\text { berhubungan } \\
\text { dengan SCM- } \\
\text { Logistik }\end{array}$ & $\begin{array}{c}0.5 \\
9\end{array}$ & $\begin{array}{c}0.0 \\
31 \\
2\end{array}$ \\
\hline \multirow{2}{*}{$\begin{array}{l}\text { Kola } \\
\text { boras } \\
\text { i } \\
\text { ranta } \\
\text { i } \\
\text { pasok }\end{array}$} & \multirow{2}{*}{0.16} & $\begin{array}{l}\mathrm{SC} \\
\mathrm{C} 1\end{array}$ & $\begin{array}{l}\text { Kolaborasi pada } \\
\text { pengembangan } \\
\text { logistik dengan } \\
\text { partner bisnis } \\
\text { yang sama }\end{array}$ & $\begin{array}{c}0.6 \\
7\end{array}$ & $\begin{array}{c}0.1 \\
07 \\
2\end{array}$ \\
\hline & & $\begin{array}{l}\mathrm{SC} \\
\mathrm{C} 2\end{array}$ & $\begin{array}{l}\text { Kolaborasi pada } \\
\text { pengembangan } \\
\text { logistik dengan } \\
\text { institusi riset dan } \\
\text { pengembangan, } \\
\text { universitas, dll }\end{array}$ & $\begin{array}{c}0.3 \\
3\end{array}$ & $\begin{array}{c}0.0 \\
52 \\
9\end{array}$ \\
\hline
\end{tabular}

\begin{tabular}{|c|c|c|}
\hline \multicolumn{3}{|c|}{ Prioritas KPI } \\
\hline $\begin{array}{l}\text { LE } \\
\text { P7 }\end{array}$ & $\begin{array}{l}\text { Total biaya } \\
\text { logistik }\end{array}$ & $\begin{array}{l}0.0 \\
07 \\
7\end{array}$ \\
\hline $\begin{array}{l}\text { IT } \\
\text { M } \\
2\end{array}$ & $\begin{array}{l}\text { Penggunaan } \\
\text { efektif komputer } \\
\text { dalam operasi } \\
\text { dan pengambilan } \\
\text { keputusan antara } \\
\text { perusahaan dan } \\
\text { mitra bisnis }\end{array}$ & $\begin{array}{l}0.0 \\
07 \\
1\end{array}$ \\
\hline $\begin{array}{l}\text { LE } \\
\text { P6 }\end{array}$ & $\begin{array}{l}\text { Lingkungan } \\
\text { kerja organisasi }\end{array}$ & $\begin{array}{l}0.0 \\
03 \\
8\end{array}$ \\
\hline
\end{tabular}

Gambar 6

Prioritas KPI Berdasarkan Bobot Akhir

Tabel 2

Penulisan Skala Pengukuran Kinerja Strategi Bisnis Logistik

Belum dirumuskan strategi SCM-Logistik, di mana kegiatan logistik tidak dianggap penting bagi perusahaan dan tidak departemen tersendiri yang mengelola kegiatan logistik

Strategi bisnis yang tepat, jelas, dan terdapat sistem yang mendukung kegiatan SCMLogistik

Pengelompokkan kategori untuk skor kinerja berdasarkan nilai skala adalah (Phuangchampee dan Baramichai, 2010):

a. Level 1 : kinerja logistik yang sangat buruk, dimana perusahaan tidak terlibat dalam kegiatan logistik;

b. Level 2 : kinerja logistik yang buruk; c. Level 3 : kinerja logistik sudah cukup baik namun masih memerlukan banyak perbaikan secara keseluruhan;

d. Level 4 : kinerja logistik yang baik, dan

e. Level 5 : kinerja logistik yang sangat baik, dimana perusahaan melakukan yang terbaik dalam kegiatan logistik. 
Input pengisian metrik adalah kondisi kegiatan logistik yang dilakukan perusahaan menurut para responden untuk setiap KPI. Kondisi kegiatan logistik yang bersifat kualitatif ini dikuantitatifkan dalam bentuk nilai skala 1-5 sesuai ketentuan pada metrik. Proses perhitungan adalah dengan mengalikan nilai skala dengan bobot untuk setiap KPI terisi. Hasilnya berupa skor untuk setiap KPI dan total skor kinerja logistik perusahaan secara keseluruhan. Skor ini digolongkan berdasarkan kategori skor kinerja, apakah berada pada level 1, 2, 3, 4, atau 5. Skor kinerja ini kemudian dapat dibandingkan dengan perusahaan lain dalam industri yang sama (Gong et.al., 2011). Kemudian hasil pengukuran kinerja di beberapa perusahaan dapat dibuat sebuah diagram untuk memetakan posisi kinerja perusahaan. Hal ini akan memberikan masukan untuk evaluasi perusahaan dalam menentukan inisiatif perbaikan kinerja logistiknya.

Gambar 7

menunjukkan aliran sistem pengukuran kinerja logistik dari input hingga diperoleh output.

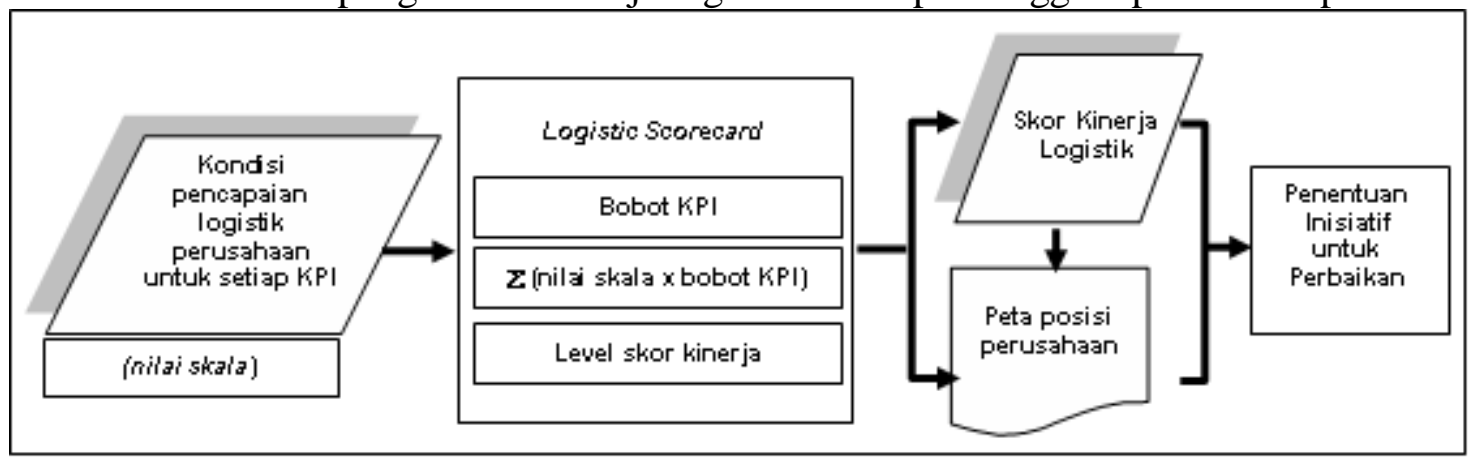

Gambar 7

Sistem Pengukuran Peningkatan Kinerja Logistik

Pada gambar di bawah disajikan gambar metrik pengukuran peningkatan kinerja logistik yang terdapat pada Gambar 8 . 
Cundo Harimurti, Model Peningkatan Kinerja Sistem Logistik Yang Efektif Dan Efisien...

FORM PENGUKURAN KINERJA LOGISTIK

Nama Perusahaan :

Penanggung Jawab Pengisian (Nama/Departemen)

Mohon untuk melingkari angka 1, 2, 3, 4, atau 5 sesuai kondisi perusahaan Anda saat ini yang mendekati

\begin{tabular}{|c|c|c|c|c|c|c|c|c|c|c|}
\hline \multirow{3}{*}{$\begin{array}{l}\text { Kode } \\
\text { BSO1 } \\
\end{array}$} & \multicolumn{7}{|c|}{ KPI Logistik } & \multirow[t]{3}{*}{ Nilai } & \multirow{3}{*}{$\begin{array}{l}\text { Bobot } \\
0.1984\end{array}$} & \multirow[t]{3}{*}{ Skor } \\
\hline & \multicolumn{7}{|c|}{ Strategi bisnis logistik } & & & \\
\hline & $\begin{array}{l}\begin{array}{l}\text { Belum dirumuskan strategi SCM-Logistik,kegiatan logistik tidak } \\
\text { dianggap penting bagi perusahaan }\end{array} \\
\end{array}$ & 1 & 2 & 3 & 4 & 5 & $\begin{array}{l}\text { Strategi bisnis yang tepat, jelas dan terdapat sistem yang mendukung } \\
\text { kegiatan SCM-Logistik }\end{array}$ & & & \\
\hline \multirow[b]{2}{*}{$\operatorname{sCC} 1$} & \multicolumn{7}{|c|}{ Kolaborasi pada pengembangan logistik dengan partner bisnis yang sama } & & \multirow[b]{2}{*}{0.1072} & \\
\hline & $\begin{array}{l}\text { Tidak menyadari pentingnya kolaborasi bagi pengembangan logistik } \\
\text { dengan partner bisnis }\end{array}$ & 1 & 2 & 3 & 4 & 5 & $\begin{array}{l}\text { Terdapat perjanjian formal dan prosedur yang jelas dalam } \\
\text { kolaborasi dengan partner bisnis bagi pengembangan logisitik } \\
\text { perusahaan }\end{array}$ & & & \\
\hline \multirow[b]{2}{*}{$\mathrm{BSO} 4$} & \multicolumn{7}{|c|}{ Sistem pengukuran dan perbaikan kepuasan pelanggan } & & \multirow[b]{2}{*}{0.1042} & \\
\hline & $\begin{array}{l}\text { Tidak ada definisi yang jelas tentang pelanggan, keluhan pelanggan } \\
\text { diselesaikan dengan cara sementara dan bijaksana. }\end{array}$ & 1 & 2 & 3 & 4 & 5 & $\begin{array}{l}\text { Peningkatan sistem pengukuran dan perbaikan kepuasan pelanggan, } \\
\text { untuk pengembangan produk dan pelayanan }\end{array}$ & & & \\
\hline \multirow[b]{2}{*}{ CWP1 } & \multicolumn{7}{|c|}{ Strategi untuk mengoptimalkan sumber daya sistem logistik } & & \multirow[b]{2}{*}{0.0867} & \\
\hline & $\begin{array}{l}\text { Tidak ada strategi perbaikan, pemanfaatan efisien dari fasilitas dan } \\
\text { sumber daya logistik tidak dilihat sebagai suatu masalah. }\end{array}$ & 1 & 2 & 3 & 4 & 5 & $\begin{array}{l}\text { Terdapat strategi yang jelas untuk kolaborasi dan optimalisasi } \\
\text { sumber daya sistem logistik }\end{array}$ & & & \\
\hline \multirow[b]{2}{*}{ BSO5 } & \multicolumn{7}{|c|}{ Sistem training pekerja dan evaluasinya } & & \multirow[b]{2}{*}{0.0644} & \\
\hline & $\begin{array}{l}\text { Tidak ada program pelatihan khusus untuk mengembangkan } \\
\text { kemampuan karyawan. }\end{array}$ & 1 & 2 & 3 & 4 & 5 & $\begin{array}{l}\text { Peningkatan sistem training dan evaluasi pekerja, terdapat sistem } \\
\text { manajemen pengetahuan untuk sharing pengetahuan }\end{array}$ & & & \\
\hline \multirow[b]{2}{*}{ CPW5 } & \multicolumn{7}{|c|}{ Standarisasi di seluruh proses bisnis } & & & \\
\hline & $\begin{array}{l}\begin{array}{l}\text { Belum terdapat standarisasi metode kerja untuk beberapa proses } \\
\text { kegiatan }\end{array} \\
\end{array}$ & 1 & 2 & 3 & 4 & 5 & $\begin{array}{l}\text { Terdapat standarisasi pada metode kerja, kegiatan antarmuka dan } \\
\text { kerjasama di seluruh rantai pasokan }\end{array}$ & & 0.0541 & \\
\hline & Kolaborasi pada pengembangan logis & tik & lenga & $\mathrm{n}$ in & titu & i ri & set dan pengembangan, universitas, dll & & & \\
\hline $5 \subset \mathrm{C} 2$ & $\begin{array}{l}\text { Tidak menyadari pentingnya kolaborasi pada pengembangan logistik } \\
\text { dengan institusi riset dan pengembangan. }\end{array}$ & 1 & 2 & 3 & 4 & 5 & $\begin{array}{l}\text { Terdapat perjanjian formal dan prosedur jelas dalam kolaborasi } \\
\text { dengan institusi riset bagi pengembangan logistik }\end{array}$ & & 0.0529 & \\
\hline & $\begin{aligned} & \text { Pemahaman tren p }\end{aligned}$ & asar & dan 1 & cete & ata & pe & ramalan permintaan & & & \\
\hline CPW2 & $\begin{array}{l}\text { Tidak terdapat aktivitas peramalan yang dilakukan dalam proses } \\
\text { rantai pasok. }\end{array}$ & 1 & 2 & 3 & 4 & 5 & $\begin{array}{l}\text { Peramalan permintaan didasarkan pada tren pasar, dilakukan } \\
\text { bersama mitra rantai pasok, dan bersifat fleksibel }\end{array}$ & & 0.0483 & \\
\hline & Kemampuan menyes & suail & can d & enga & a pe & en & canaan SCM-Logistik & & & \\
\hline CPW3 & $\begin{array}{l}\text { Tidak ada rencana untuk penjualan, penambahan, dan pengiriman } \\
\text { yang dilakukan. }\end{array}$ & 1 & 2 & 3 & 4 & 5 & $\begin{array}{l}\text { Peningkatan kemampuan perencanaan. Terdapat data penjualan, } \\
\text { manajemen persediaan, pengiriman }\end{array}$ & & 0.0460 & \\
\hline & Perjanjian kontrak d & $\operatorname{lan}{ }_{1}$ & ertul & cara & $\inf$ & $\mathbf{r m}$ & asi dengan pelanggan & & & \\
\hline $\mathrm{BSO} 3$ & $\begin{array}{l}\text { Tidak terdapat perjanjian tertulis yang formal dan kegiatan sharing } \\
\text { dengan pelanggan. Pelanggan selalu melakukan pengambilan } \\
\text { keputusan. }\end{array}$ & 1 & 2 & 3 & 4 & 5 & $\begin{array}{l}\text { Terdapat perjanjian tertulis yang formal dengan seluruh pelanggan, } \\
\text { kegiatan sharing, dan rencana pengembangan pelanggan yang mapan }\end{array}$ & & 0.0352 & \\
\hline & & rbai & $\operatorname{kan} 1$ & egi & $\tan$ & ogi & & & & \\
\hline LEP1 & $\begin{array}{l}\text { Tidak ada rencana perbaikan kegiatan logistik, flosofi just-in-time } \\
\text { tidak dipraktikkan perusahaan. }\end{array}$ & 1 & 2 & 3 & 4 & 5 & $\begin{array}{l}\text { Terdapat perbaikan kegiatan logistik yang berkelanjutan yang } \\
\text { melibatkan pelanggan dan pemasok. }\end{array}$ & & 0.0331 & \\
\hline & Pengembangan personi & $\mathrm{ITI}$ & yang & berl & ubu & ga & n dengan SCM-Logistik & & & \\
\hline ITM3 & $\begin{array}{l}\text { Perusahaan tidak memiliki kepedulian pada pengembangan personil } \\
\text { TI yang berhubungan dengan kegiatan SCM-Logistik }\end{array}$ & 1 & 2 & 3 & 4 & 5 & $\begin{array}{l}\text { Terdapat pelatihan bagi personil di bidang TI yang berhubungan } \\
\text { dengan kegiatan SCM-Logistik }\end{array}$ & & 0.0312 & \\
\hline & Perjanjian kontrak & dan & pertu & kara & $\mathrm{ain}$ & orm & tasi dengan pemasok & & & \\
\hline $\mathrm{BSO} 2$ & $\begin{array}{l}\text { Tidak terdapat perjanjian tertulis yang formal dan kegiatan sharing } \\
\text { dengan pemasok. Pengambilan keputusan dilakukan secara mandiri. }\end{array}$ & 1 & 2 & 3 & 4 & 5 & $\begin{array}{l}\text { Terdapat perjanjian tertulis yang formal dengan seluruh pemasok, } \\
\text { kegiatan sharing, dan rencana pengembangan pemasok yang mapan }\end{array}$ & & 0.0281 & \\
\hline & Sistem mo & nito & ring & $\operatorname{lan} \mathrm{t}$ & ack & ng & persediaan & & & \\
\hline CPW4 & Tidak ada pengawasan dan tracking persediaan. & 1 & 2 & 3 & 4 & 5 & $\begin{array}{l}\text { Terdapat pengawasan dan tracking persediaan yang bersifat } \\
\text { transparan, dan sharing informasi di seluruh rantai pasokan }\end{array}$ & & 0.0168 & \\
\hline & Standar pengidentifi & kasi & an $(\mathrm{k}$ & ode) & 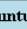 & $\mathbf{k} \mathbf{p}$ & roduk maupun proses & & & \\
\hline ITM1 & $\begin{array}{l}\text { Tidak dialokasikannya standar identifikasi (kode) untuk produk dan } \\
\text { proses manapun dalam perusahaan. }\end{array}$ & 1 & $?$ & 3 & 4 & 5 & $\begin{array}{l}\text { Terdapat standar identifikasi (kode) untuk seluruh produk dan } \\
\text { proses yang diketahui pemasok dan pelanggan }\end{array}$ & & 0.0148 & \\
\hline & Lead tim & e pe & lange & 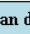 & an e & isie & ensi beban & & & \\
\hline LEP3 & $\begin{array}{l}\text { Tidak diketahuinya lead-time untuk penempatan pemesanan untuk } \\
\text { produk manapun. }\end{array}$ & 1 & 2 & 3 & 4 & 5 & $\begin{array}{l}\text { Terdapat upaya yang terus-menerus dilakukan untuk menurunkan } \\
\text { lead-time dan meningkatkan efisiensi beban }\end{array}$ & & 0.0148 & \\
\hline & Kinerja c & dan & kuali & as $\mathrm{p}$ & engi & ima & an produk & & & \\
\hline LEP4 & $\begin{array}{l}\text { Tidak diketahuinya tingkat pengiriman tepat waktu dan akurasi } \\
\text { pemenuhan pesanan, sehingga perusahaan menghadapi banyak } \\
\text { keluhan pelanggan. }\end{array}$ & 1 & 2 & 3 & 4 & 5 & $\begin{array}{l}\text { Tercapainya target tingkat pengiriman tepat waktu dan akurasi } \\
\text { pemenuhan pesanan, dengan upaya peningkatan berkelanjutan }\end{array}$ & & 0.0138 & \\
\hline & Penger & mba & ngan & dep & rter & en & logistik & & & \\
\hline CPW6 & $\begin{array}{l}\text { Tidak ada satupun yang bertanggungjawab untuk kegiatan logistik } \\
\text { dalam perusahaan. }\end{array}$ & 1 & 2 & 3 & 4 & 5 & $\begin{array}{l}\text { Terdapat rencana pengembangan (pelatihan, perekrutan) personil di } \\
\text { departemen logistik untuk perbaikan berkelanjutan }\end{array}$ & & 0.0133 & \\
\hline & Sist & em & nanaj & eme & a pe & se & liaan & & & \\
\hline LEP5 & $\begin{array}{l}\text { Tidak terdapat sistem manajemen perse diaan yang baik, dimana } \\
\text { target level stok belum ditentukan oleh perusahaan. }\end{array}$ & 1 & 2 & 3 & 4 & 5 & $\begin{array}{l}\text { Terdapat sistem manajemen persediaan yang baik: tercapainya } \\
\text { target dalam mengurangi penyimpangan level stok }\end{array}$ & & 0.0098 & \\
\hline & Perputaran pe & isec & liaan & dan & cash & to- & cash cycle time & & & \\
\hline LEP2 & $\begin{array}{l}\text { Tidak diukurnya perputaran persediaan maupun cash-to-cash cycle } \\
\text { time. }\end{array}$ & 1 & 2 & 3 & 4 & 5 & \begin{tabular}{|l|} 
Terdapat pengukuran perputaran persediaan dan cash-to-cash cycle \\
time seluruh produk, dan rencana perbaikan berkelanjutan
\end{tabular} & & 0.0083 & \\
\hline & & & tal bi & aya & ogis & & & & & \\
\hline LEP7 & Tidak diketahuinya biaya logistik pada proses manapun. & 1 & 2 & 3 & 4 & 5 & $\begin{array}{l}\text { Tercapainya target penurunan biaya logistik pada setiap proses } \\
\text { dengan strategi yang telah ditentukan }\end{array}$ & & 0.0077 & \\
\hline & Penggunaan efektif dari komputer dalam ope & rasi & $\operatorname{dan}_{1}$ & eng & $\mathrm{mb}$ & an & keputusan antara perusahaan dan mitra bisnis & & & \\
\hline ITM2 & $\begin{array}{l}\text { Tidak digunakannya alat TI (seperti komputer) dimanapun dalam } \\
\text { bisnis. }\end{array}$ & 1 & 2 & 3 & 4 & 5 & $\begin{array}{l}\text { Digunakannya alat-alat TI secara efektif dalam operasi dan } \\
\text { pengambilan keputusan }\end{array}$ & & 0.0071 & \\
\hline & & gko & ngan & kerj & or & ani & sasi & & & \\
\hline LEP6 & $\begin{array}{l}\text { Rendahnya tingkat kepedulian terhadap lingkungan kerja bagi } \\
\text { kesejahteraan staff. }\end{array}$ & 1 & 2 & 3 & 4 & 5 & $\begin{array}{l}\text { Terdapat inisiatif untuk menciptakan lingkungan kerja yang kondusif, } \\
\text { nyaman, aman, telah tersertifikasi (ISO 14000) }\end{array}$ & & 0.0038 & \\
\hline
\end{tabular}

Gambar 8

Metrik Pengukuran Peningkatan Kinerja Logistik (Logistic Scorecard)

\subsection{Verifikasi dan Validasi Model}


JURNAL LOGISTIK INDONESIA

Majalah Ilmiah Institut STIAMI

ISSN 2579-8952
Verifikasi dan validasi dilakukan untuk model yang telah dirancang, apakah model benar dan konsisten secara logis dan sesuai dengan kondisi nyata. Tahapan ini meliputi wawancara dengan pakar mengenai model yang dirancang, menerapkan model untuk mengukur kinerja logistik di perusahaan komponen otomotif, kemudian dilakukan analisis terhadap hasil penelitian.

\section{Verifikasi}

Verifikasi model dilakukan dengan menerapkan model untuk mengukur peningkatan kinerja logistik PT. ABC. Verifikasi bertujuan untuk mengetahui apakah parameter dan langkah-langkah dalam model dapat digunakan dengan benar untuk mengukur kinerja logistik di PT. ABC hingga diperoleh nilai skor akhir peningkatan kinerja logistik. Pengukuran peningkatan kinerja logisitik melibatkan dua orang responden sebagai pakar, yaitu Direktur PT. ABC dan Kepala Departemen Warehouse \& Logistik. Pengukuran dilakukan dengan wawancara untuk menanyakan bagaimana pencapaian kegiatan proses bisnis logistic perusahaan yang dirinci pada setiap KPI logistic pada model.

Hasil pengukuran diperoleh skor peningkatan kinerja logistik PT. ABC sebesar 3.05 dari skala 5 dan berada pada klasifikasi level 3 atau cukup baik. Dengan demikian, dapat dikatakan bahwa terdapat peningkatan kinerja sistem logistik PT. ABC ke arah lebih efektif dan efisien, kendatipun masih terdapat beberapa hal yang memerlukan perbaikan secara keseluruhan dalam sistem logistiknya.

Hasil verifikasi menunjukkan bahwa model pengukuran peningkatan kinerja yang dirancang telah terverifikasi untuk dapat digunakan mengukur kinerja sistem logistik perusahaan sesuai dengan kondisi proses bisnis kegiatan rantai pasok-logistik perusahaan dengan menghasilkan keluaran yang sesuai.

\section{Validasi}

Validasi model dilakukan untuk menjelaskan bahwa model pengukuran peningkatan kinerja sistem logistik yang dirancang layak untuk diimplementasikan pada sistem nyata, yakni dapat digunakan untuk mengukur peningkatan kinerja sistem logistik PT. ABC serta diterapkan pada setiap perusahaan dalam industri sejenis di Indonesia.

Validasi dilakukan dengan menggunakan teknik face validity, yaitu dengan bertanya kepada orang yang memiliki pengetahuan mengenai sistem apakah model dan atau perilakunya dapat diterima (Sargent, 2013). Validasi dilakukan oleh praktisi di industri komponen otomotif yaitu Direktur PT. ABC dan Kepala Departemen Warehouse \& Logistik, serta pihak akademisi expert di bidang rantai pasok-logistik.

Aspek-aspek yang dipertimbangkan dalam proses validasi antara lain: 
Cundo Harimurti, Model Peningkatan Kinerja Sistem Logistik Yang Efektif Dan Efisien...

1) Langkah-langkah penentuan KPI yang dimulai dari identifikasi strategi hingga penentuan indikator kinerja dan target berdasarkan strategi.

2) KPI bersifat representatif untuk perusahaan komponen otomotif.

3) Urutan prioritas KPI pada model merupakan KPI yang benar menjadi indikator kritis bagi peningkatan kinerja sistem logistik perusahaan komponen otomotif.

4) Model pengukuran peningkatan kinerja sistem logistik yang dirancang dapat diimplementasikan di perusahaan dalam industri sejenis di Indonesia, sebagai pedoman dalam peningkatan daya saing.

Hal penting yang diperoleh dari hasil validasi adalah:

1) Kesesuaian langkah-langkah dalam menentukan KPI, dimana diperolehnya KPI adalah dari strategi yang diturunkan dari visi-misi dan analisa faktor internal dan eksternal.

2) KPI yang ditentukan representatif untuk pengukuran peningkatan kinerja sistem logistik yang bersifat kualitatif bagi perusahaan-perusahaan dalam industri sejenis. KPI sesuai dengan tuntutan untuk meningkatkan daya saing kineja sistem logistik.

3) Urutan prioritas KPI dirasa sesuai, salah satu contoh adalah strategi bisnis logistik merupakan KPI yang benar menjadi indikator kritis bagi peningkatan kinerja sistem logistik perusahaan komponen otomotif.

4) Model pengukuran peningkatan kinerja sistem logistik yang dirancang dapat diimplementasikan di perusahaan dalam industri sejenis di Indonesia dikarenakan KPI yang digunakan untuk peningkatan daya saing kinerja sistem logistik tidak jauh berbeda antara satu perusahaan dengan perusahaan lain.

5) Fleksibilitas untuk mengembangkan KPI sesuai dengan kebutuhan dan perkembangan perusahaan, dimana penentuan KPI berasal dari strategi perusahaan. Sehingga model ini dapat digunakan di industri sejenis lain.

\subsection{Implementasi Model}

Pengukuran kinerja logistik dilakukan di empat sampel perusahaan komponen otomotif dengan menggunakan model yang telah dirancang, yaitu form Logistics Scorecard. Form ini ditujukan untuk diisi oleh pihak perusahaan yang menduduki posisi minimal supervisor di departemen terkait yang melakukan kegiatan logistik, atau para petinggi perusahaan yang mengetahui seluruh proses bisnis khususnya logistik perusahaan. Ketentuan pengisian dapat dilakukan oleh lebih dari 1 orang, yang mengisi masingmasing nilai KPI sesuai pengetahuannya yang sebenarnya mengenai kondisi di perusahaan, atau dengan jawaban hasil diskusi. 


\section{JURNAL LOGISTIK INDONESIA}

Majalah Ilmiah Institut STIAMI

ISSN 2579-8952

Hasil pengukuran dan analisis peningkatan kinerja sistem logistik memberikan informasi bahwa PT. ABC masih berada pada lebih yang lebih rendah dibandingkan kinerja logistik perusahaan komponen otomotif lain yang berskala perusahaan lebih besar. Adapun hasil ratarata penilaian kinerja logistik industri komponen otomotif adalah 3.9, dengan kategori kinerja logistik cukup baik. Rata-rata perusahaan memiliki kelemahan pada implementasi teknologi informasi seperti penggunaan komputer yang terintegrasi, masih kurangnya staff TI yang berhubungan dengan kegiatan logistik, serta adanya standar pengkodean produk dan proses.

Lemahnya teknologi informasi ini dapat berdampak pada KPI lainnya, dimana teknologi informasi kini menjadi faktor penting yang mendukung kelancaran proses bisnis logistik baik di internal perusahaan maupun dengan eksternal perusahaan atau mitra bisnis. Industri komponen otomotif nasional juga masih memiliki kelemahan pada standarisasi seluruh proses bisnis dan departemen logistik yang masih perlu dikembangkan.

\section{E. Kesimpulan dan Saran}

Berdasarkan hasil penelitian dapat dilakukan penarikan kesimpulan sebagai berikut:

1. Sistem pengukuran peningkatan kinerja sistem logistik ini didasarkan pada strategi kegiatan bisnis logistik industri komponen otomotif dalam menghadapi MEA, yang diturunkan dari visi-misi, tujuan, serta strategi perusahaan untuk menggunakan kekuatan dan peluang yang ada untuk meminimalisir kelemahan perusahaan dan ancaman dari adanya pasar bebas MEA.

Dari strategi ini diperoleh indikator yang dijadikan sebagai tolok ukur pengukuran beserta targetnya, yang dikelompokkan berdasarkan lima perspektif Logistics Scorecard.

2. Terdapat 23 KPI logistik yang dikelompokkan masing-masing menurut perspektif Logistics Scorecard, yaitu 5 KPI perspektif orientasi strategi bisnis, 6 KPI perspektif perencanaan kapasitas dan pelaksanaan, 7 KPI perspektif efisiensi dan produktivitas logistik, 3 KPI perspektif implementasi teknologi informasi, dan 2 KPI perspektif kolaborasi rantai pasok.

KPI digunakan sebagai tolok ukur kinerja logistik yang berdaya saing.

3. Urutan prioritas kelima perspektif berdasarkan bobot tertinggi adalah orientasi strategi bisnis, perencanaan kapasitas dan pelaksanaan, kolaborasi rantai pasok, efisiensi dan produktivitas logistik, dan implementasi teknologi informasi.

4. Prioritas KPI yang memiliki bobot akhir tertinggi adalah strategi bisnis logistik dari perspektif orientasi strategi bisnis, KPI ini menjadi hal utama yang harus terlebih dahulu ditentukan sebelum mengimplementasikan strategi peningkatan kinerja sistem logistik perusahaan.

5. Model pengukuran peningkatan kinerja yang dirancang dapat digunakan untuk mengukur peningkatan kinerja sistem logistik perusahaan komponen otomotif di Indonesia, karena KPI yang digunakan sebagai tolok ukur 
Cundo Harimurti, Model Peningkatan Kinerja Sistem Logistik Yang Efektif Dan Efisien...

peningkatan daya saing kinerja logistik tidak jauh berbeda antara satu perusahaan dengan lainnya. Model ini juga selanjutnya dapat digunakan bagi industri sejenis lain dimana KPI bersifat fleksibel untuk dikembangkan sesuai kebutuhan dan perkembangan perusahaan.

6. Rata-rata perusahaan memiliki skor rendah pada KPI implementasi TI dan strategi bisnis, sehingga hal ini dapat dijadikan pertimbangan untuk peningkatan di bidang teknologi khususnya teknologi informasi serta pembuatan strategi bisnis logistik yang lebih baik.

Berdasarkan kesimpulan di atas, maka dapat diajukan saran sebagai berikut:

1. Model sebaiknya dapat digunakan oleh pihak-pihak terkait untuk evaluasi industri komponen otomotif dalam rangka peningkatan kinerja sistem logistik yang berdaya saing.

2. Para stakeholders dan pihak yang terkait dalam pengembangan industri komponen otomotif maupun masingmasing perusahaan sebaiknya agar dapat menentukan kebijakan berdasarkan hasil pengukuran peningkatan kinerja.

3. Penerapan model sebaiknya dilakukan dengan lebih intensif dan waktu yang lebih lama untuk memperoleh hasil yang lebih akurat. Pernyataan KPI dan target dalam model juga dapat lebih disederhanakan agar lebih dapat dipahami oleh pengguna model di perusahaan. Oleh karena itu, untuk kemudahan dalam penerapan model pengukuran peningkatan kinerja sistem logistik ini sebaiknya perlu dibuat suatu buku pedoman.

4. Penelitian selanjutnya diharapkan dapat mempertajam indikatorindikator peningkatan kinerja sistem logistik (KPI) dengan menyesuaikan pada kebutuhan dan perkembangan industri atau masing-masing perusahaan.

5. Penilaian yang bersifat kuantitatif untuk pengukuran kinerja logistik dalam rangka penguatan daya saing sebaiknya dapat dikembangkan pada penelitian-penelitian selanjutnya.

\section{DAFTAR PUSTAKA}

Anatan, Lina. 2010. Pengaruh Implementasi Praktik-Praktik Manajemen Rantai Pasokan terhadap Kinerja Rantai Pasok dan Keunggulan Kompetitif. Karisma, Vol.4(2), pp.106-117.

Armitage, H.M. dan Cameron Scholey. 2006. Using Strategy Maps to Drive Performance. Canada: The Society of Management Accountants of Canada, The American Institute of Certified Public Accountants and The Chartered Institute of Management Accountants.

Barnard, James. 2006. A Multi Framework for Defining The Services Supply Chain Using Object Oriented Methodology. Florida: Univ. of Florida.

Brewer, P. dan Thomas Speh. 2000. Using The Balanced Scorecard to Measure Supply Chain Performance. Journal of Business Logistics, Vol.21, No.1, pp. 75-93.

Choy, K., Chow, H., Lee, W. and Chan, F. 2007. Development of Performance Measurement System in Managing Supplier Relationship for Maintenance Logistics Providers. Benchmarking: An International Journal, Vol. 14 No. 3, pp. 352-68.

Departemen Perdagangan Republik Indonesia. 2009. Buku Menuju Asean Economy Community 2015. http://ditjenkpi.kemendag.go.id/webs ite_kpi/Umum/Setditjen/Buku\%20M enuju\%20ASEAN\%20ECONOMIC \%20COMMUNITY\%202015.pdf.

Eadie, R. et.al. 2010. Identification of EProcurement Drivers and Barriers for UK Construction Organisations and Ranking of these from the 


\section{JURNAL LOGISTIK INDONESIA}

Majalah Ilmiah Institut STIAMI

ISSN 2579-8952

Perspective of Quantity Surveyors. Journal of Information Technology in Construction, Vol.15, pp. 23-43.

Gong, J., Ogasawara, T., dan Suzuki, S. 2011. Supply Chain Operational Performance and Its Influential Factors: Cross National Comparison between Japan and China. Brazilian Journal of Operations \& Production Management, 8, 2nd ser.,pp.67-87.

Haryotejo, Bimo. 2015. Analisis Pengaruh Kinerja Logistik Pemasok terhadap Kinerja Bisnis (Studi pada Bengkel AHASS di Kota Semarang). Semarang: Fakultas Ekonomika dan Bisnis Universitas Diponegoro.

Hashemi, Nima F., et.al. 2012. Formulating and Choosing Strategies using SWOT Analysis and QSPM Matrix: A Case Study of Hamadan Glass Company. Proceedings of The 41st International Conference on Computers \& Industrial Engineering.

Heizer, J dan Barry Render. 2014. Operations Management: Sustainability and Supply Chain Management. Pearson.

Kementrian Luar Negeri Republik Indonesia. 2014. Kerjasama Ekonomi ASEAN. www.kemlu.go.id/Documents/Kerjas ama\%20Ekonomi\%20ASEAN.doc.

Li, S., Nathan, B. R., Nathan, T. S., \& Rao, S. S. 2006. The Impact of Supplychain Management Practices on Competitive Advantage and Organizational Performance. Omega. 34: 107-124.

Mensah, C., D.Diyuoh, D.Oppong. 2014. Assessment of Supply Chain Management Practices and It Effects on The Performance of Kasaprekko Company Limited in Ghana. European Journal of Logistics Purchasing and Supply Chain Management, Vol. 2 No. 1, pp. 1-16.

Mulyadi, Dedi. 2011. Pengembangan Sistem Logistik yang Efisien dan Efektif
Volume 01, Nomor 01, April 2018

dengan Pendekatan Supply Chain Management. Jurnal Riset Industri, Vol. V, No.3, pp.275-282.

Mutakin, A. dan M. Hubeis. 2011. Pengukuran Kinerja Manajemen Rantai Pasokan dengan SCOR Model 9.0. Jurnal Manajemen dan Organisasi, Vol.II, No.3, pp.89-103.

Pohlen, T. dan Coleman, B. 2005. Evaluating Internal Operations and Supply Chain Performance Using EVA and ABC. SAM Advanced Management Journal, Vol. 70 No. 2, pp. 45-58.

Primiana, Ina. 2012. Logistik dan Daya Saing. Jakarta : LP3E Kadin Indonesia.

Puangchampee, B. dan M.Baramichai. 2010. Thailand Industrial Competitiveness; Enhancing The Logistics and Supply Chain Management Scheme for Thai's Manufacturing. 2010 International Conference on Management Science and Information Engineering (ICMSIE 2010), UTCC Engineering Research Papers 2010, pp.203-206.

Saboia, E., L.C.Duclos, C.O.Quandt, A.Souza. $2006 . \quad$ Strategic Management Indicators for Internal Logistics: A Proposal Based on The Balanced Scorecard for An Automotive Sector Company. XII ICIEOMFortaleza, CE, Brasil.

Sargent, R.G. 2013. Verification and Validation of Simulation Models. Journal of Simulation, Vol.7, pp. 1224.

Sorooshian, S. dan Yin, D.T. 2013. Logistics Evaluation: a Case Study. International Journal of Engineering \& Technology Sciences, Vol.1, No.4, pp.192-199.

Tracey, M., Lim, J. and Vondrembse, M. 2005. The Impact of Supply Chain Management Capabilities on Business Performance. Supply Chain Management: An International Journal, Vol. 10 No. 3, pp. 179-91. 
Cundo Harimurti, Model Peningkatan Kinerja Sistem Logistik Yang Efektif Dan Efisien... 